\title{
Seismic methods in mineral exploration and mine planning: A general overview of past and present case histories and a look into the future
}

\author{
Alireza Malehmir ${ }^{1}$, Raymond Durrheim ${ }^{2}$, Gilles Bellefleur ${ }^{3}$, Milovan Urosevic ${ }^{4}$, \\ Christopher Juhlin ${ }^{1}$, Donald John White ${ }^{3}$, Bernd Milkereit ${ }^{5}$, and Geoff Campbell ${ }^{6}$
}

\begin{abstract}
Due to high metal prices and increased difficulties in finding shallower deposits, the exploration for and exploitation of mineral resources is expected to move to greater depths. Consequently, seismic methods will become a more important tool to help unravel structures hosting mineral deposits at great depth for mine planning and exploration. These methods also can be used with varying degrees of success to directly target mineral deposits at depth. We review important contributions that have been made in developing these techniques for the mining industry with focus on four main regions: Australia, Europe, Canada, and South Africa. A wide range of case studies are covered, including some that are published in the special issue accompanying this article, from surface to borehole seismic methods, as well as petrophysical data and seismic modeling of mineral deposits. At present, high-resolution 2D surveys mostly are performed in mining areas, but there is a general increasing trend in the use of 3D seismic methods, especially in mature mining camps.
\end{abstract}

\section{INTRODUCTION}

If it is possible to see clearly below a mine site and map the location or extension of the resources there, the cost of production would decrease, and the return on invested capital infrastructure would increase. This is the holy grail of the mineral industry. To see below the surface, the mineral industry employs various geophysical methods. Potential field and electromagnetic methods have been traditionally, and successfully, used in mineral exploration to delineate potential mineralized zones and also discover resources at shallower depths. However, the only surface method that can provide high-definition images of the underground and has the required depth of penetration is the seismic reflection method. The potential of the method for mine planning and exploration has been long known (e.g., Schmidt, 1959; Oblogina et al., 1962; Elliot, 1967; Gupta, 1971; Reid et al., 1979; Hawkins and Whiteley, 1980; Kehrman, 1980; Ruskey, 1981; Wright, 1981; Gladwin, 1982; Nelson, 1980, 1984; Cosma, 1983; Wong et al., 1983; Campbell and Peace, 1984; Gustavsson et al., 1984; Dahle et al., 1985; Galperin, 1985; Fatti, 1987; Mutyorata, 1987; Campbell and Crotty, 1988; Duncan, 1989; Pretorius et al., 1989; Read, 1989; Young et al., 1989; Gendzwill, 1990; Juhlin et al., 1991; Maxwell and Young, 1992; Milkereit et al., 1992c; Spencer et al., 1993; Cao and Greenhalgh, 1995; Frappa and Moinier, 1993; Friedel et al., 1995, 1996; Milkereit et al., 1996; Salisbury et al., 1996; Greenhalgh and Mason, 1997; Hajnal et al., 1997; Urosevic and Evans, 1998; Greenhalgh and Bierbaum, 1998; Urosevic and Evans, 2000; Duweke et al., 2002; Eaton et al., 2003; Perron et al., 2003; Chen et al., 2004), especially 3D seismics, but its full application and acceptance by the mining industry started only recently. This acceptance is mainly due to the ability of seismic methods to provide high-resolution images of subsurface structures, and the fact that they have greater penetration with sufficient resolution, compared with other geophysical methods and can, therefore, better complement drilling and exploration programs. However, as is evidenced in several studies (e.g., Pretorius et al., 2003), the overall performance of seismic methods is highly site- and geology-dependent. The present trend in exploration and exploitation of mineral resources

Manuscript received by the Editor 24 January 2012; revised manuscript received 20 May 2012; published online 7 September 2012.

${ }^{1}$ Uppsala University, Department of Earth Sciences, Uppsala, Sweden. E-mail: alireza.malehmir@geo.uu.se; christopher.juhlin@geo.uu.se.

${ }^{2}$ Council for Scientific and Industrial Research (CSIR) and University of the Witwatersrand, Johannesburg, South Africa. E-mail: raymond.durrheim@ @its.ac.za.

${ }^{3}$ Geological Survey of Canada, Ottawa, Canada. E-mail: gilles.bellefleur@nrcan-rncan.gc.ca; don.white@nrcan-rncan.gc.ca.

${ }^{4}$ Curtin University, Department of Exploration Geophysics and Deep Exploration Technologies Corporative Research Centre (DETCRC), Perth, Australia. E-mail: m.urosevic@curtin.edu.au.

${ }^{5}$ University of Toronto, Toronto, Canada. E-mail: bm@physics.utoronto.ca.

${ }^{6}$ GAP Geophysics, Johannesburg, South Africa. E-mail: gapgeo@icon.co.za.

(C) 2012 Society of Exploration Geophysicists. All rights reserved. 
at great depth is leading to an increase in the use of seismic methods for targeting deep-seated mineral deposits and for deep mine planning. Seismic methods provide high-resolution images of the geologic structures hosting mineral deposits and, in a few cases, can be used for the direct detection of mineral deposits at depths greater than $1 \mathrm{~km}$. This is not limited to only surface seismic surveys, borehole seismic methods such as vertical seismic profiling (VSP) and crosshole imaging also are increasingly being used. To date, tens of 2D and 3D surface seismic surveys have been acquired in Canada, Europe, Australia, and South Africa (Figure 1) for mineral exploration and exploitation purposes. Based on an increasing number of activities, seismic methods are slowly, but surely becoming established techniques in the mining sector. This brings new opportunities for geophysicists, but also new challenges. In this overview article, we aim to highlight worldwide recent advancements in data acquisition, processing, and imaging of mineral deposits and their host rock structures. Special focus will be given to results published in the special section of "Seismic methods in mineral exploration and mine planning" in this special issue of GEOPHYSICS. We limit our review mainly to regions in Europe, South Africa, Canada, and Australia because the articles in the special issue generally deal with these areas. However, we also review a few published accounts from early, but pioneering works, that led to the development of seismic methods in the hard-rock environment. We end the paper by looking ahead and present potential areas of future research and development in the field. Obviously, a comprehensive review covering almost all published works in hard-rock seismic environments is beyond the scope of this paper. We are aware of several unpublished reports (especially from Russia and China) and many more that are confidential at the moment; therefore, no emphasis on these areas given in this review article.

A comprehensive review of reflection seismic surveying for mineral exploration applications was provided in Reed (1993). The anomalous petrophysical properties (often density, and sometimes velocity) of massive sulfide deposits and the application of seismic methods to explore for them were presented by Milkereit et al. (1996). Subsequently, several papers were published presenting the successful application of seismic methods for hard-rock exploration (e.g., Eaton et al., 2003).

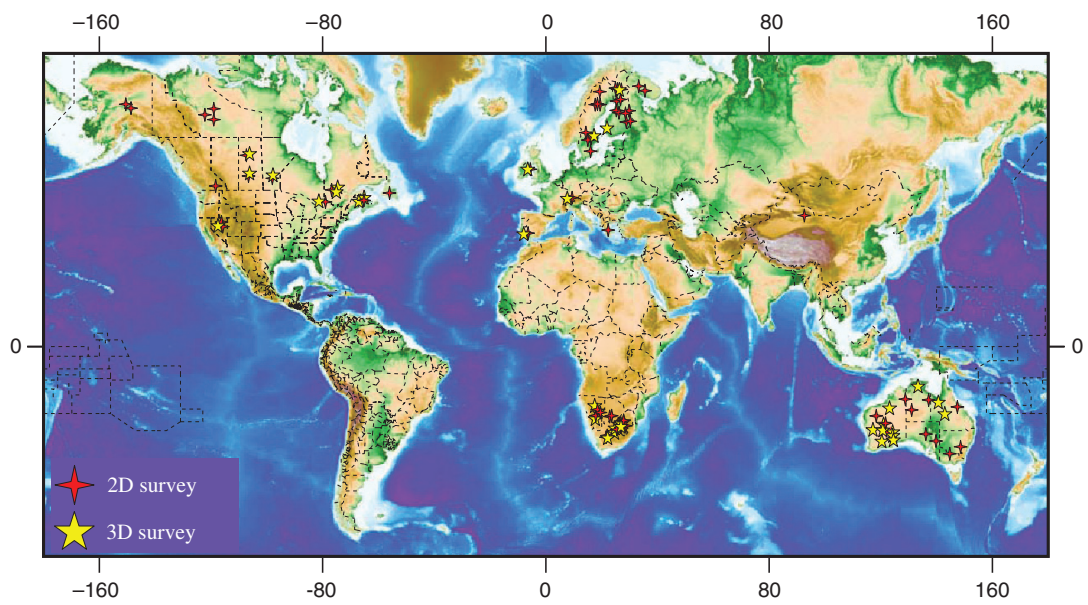

Figure 1. World map showing the locations of existing 2D and 3D hard-rock seismic surveys conducted for mineral exploration, site characterizations, and mine planning.
Early work by geologic surveys indicated that the crystalline basement also was a target for seismic reflection profiling (e.g., Moss and Jones, 1974; Mathur et al., 1977). However, an important catalyst for the application of seismic methods for mineral exploration was the successful imaging of fault and fracture zones in the hard-rock environment for the characterization of nuclear-waste repository sites (Noponen et al., 1979; Mair and Green, 1981; Green and Mair, 1983; Juhlin et al., 1991; Juhlin, 1995; Cosma et al., 2001; Juhlin and Stephens, 2006). Large-scale seismic investigations in Canada (e.g., Lithoprobe), the USA (e.g., COCORP), Australia (AGSO), Europe (Europrobe), and South Africa (National Geophysics Programme) also were very important in developing the necessary techniques for imaging challenging and complex geologic structures in the crystalline environment (e.g., Ruskey, 1981; Clowes et al., 1984; Milkereit et al., 1992c; Juhlin et al., 1995; Milkereit et al., 1996; Milkereit and Eaton, 1998; Ayarza et al., 2000; Durrheim et al., 1991, Odgers et al., 1993; Calvert et al., 2003; Eaton et al., 2010). Extensive 2D seismic surveys to map the structure and explore for extensions of the gold-bearing Witwatersrand Basin of South Africa commenced in the early 1980s (Campbell and Peace, 1984; Durrheim, 1986; Pretorius et al., 1989; Chambovet et al., 2006). The first 3D seismic survey for mineral exploration was conducted in South Africa in 1987 (Campbell and Crotty, 1990; Campbell, 1994). Shortly thereafter, a 3D seismic survey for $\mathrm{Ni}-\mathrm{Cu}$ exploration was conducted in the Sudbury complex in 1995 (Milkereit et al., 1996, 2000). Between 19962002, Noranda Inc. (now Xstrata) supported a large number of 2D and 3D seismic surveys for the purpose of deep exploration $(<1500 \mathrm{~m})$ in Canada. Adopting an approach of cost-benefit evaluation of 3D seismic used in hydrocarbon exploration, Pretorius et al. (1997) conducted the first successful application of 3D seismic for mine planning and development. The first successful 3D seismic delineation of a blind massive sulfide deposit was reported from the western part of the Bathurst mining camp, in the Halfmile Lake area, Canada, at a depth of about $1.2 \mathrm{~km}$ (Matthews, 2002; Bellefleur et al., 2004b; Malehmir and Bellefleur, 2009). These surveys were well integrated with petrophysical measurements carried out in boreholes and in the laboratory to constrain the seismic interpretations. Multidisciplinary works for studying large-scale structures hosting mineral deposits also are reported by several authors in Australia (e.g., Goleby et al., 2002; Evans et al., 2003; Williams et al., 2004; Stolz et al., 2004; Urosevic et al., 2005), in Canada (Roy and Clowes, 2000), and in Europe (Juhlin et al., 2002; Korja and Heikkinen, 2005; Malehmir et al., 2006, 2007).

\section{SEISMIC TECHNIQUES AND THEIR BASIS}

\section{Petrophysical measurements and target considerations}

Eaton et al. (2010) report that it was when laboratory measurements for acoustic properties were being carried out during the Lithoprobe project (e.g., Salisbury et al., 1996) that the strong reflective character of massive sulfide deposits in typical volcano sedimentary rocks was accidentally discovered. Salisbury et al. (1996, 2003) performed systematic measurements of velocities and densities of massive sulfides and their host rocks (also see Ji et al., 2002). They showed that these 
deposits invariably lie far to the right of the Nafe-Drake curve in crossplots of velocity against density, mainly due to their very high density (Figure 2). Note that massive sulfides rich in pyrite (a noneconomic sulfide mineral) tend to have higher velocities (e.g., those reported from Lokken Verk in Norway), whereas massive sulfides rich in pyrrhotite (e.g., those reported from Kristineberg and Flin Flon in Sweden and Canada, respectively) tend to fall along the mixing lines between pure pyrrhotite and mafic host rocks (Figure 2). Case studies presented in this special section (e.g., Dehghannejad et al., 2012; Duff et al., 2012; Malehmir et al., 2012a; Malinowski et al., 2012) are consistent with this observation. Malehmir et al. (2011) report that magnetite-rich $(>40 \% \mathrm{Fe}$ ) iron deposits show a significant acoustic impedance contrast against almost all lithologies (see Figure 2).

Successful imaging of mineral deposits and their host rock structures (including fractures and faults), apart from a prerequisite of significant contrast in the seismic velocity and density, requires that the target dimension and geometry are considered. Typical seismic wavelengths for waves propagating in the hard-rock environment are on the order of $50-100 \mathrm{~m}$, a value that increases with depth. Therefore, targets located at about $1000 \mathrm{~m}$ depth cannot be resolved vertically and horizontally if they are less than about $20 \mathrm{~m}$ thick and $350 \mathrm{~m}$ long, respectively. Targets thinner than $20 \mathrm{~m}$ still can be detected, but their amplitude will be mainly dependent on the geometry of the target and not solely on the impedance contrast. Targets horizontally shorter than $350 \mathrm{~m}$ also can be detected, but the response will be a combination of reflections and diffractions (e.g., Eaton, 1999; Bohlen et al., 2003). Most economical-sized exploration targets, if they have no clear reflection character, fall within the so-called Mie-scattereing regime (Eaton et al., 2003), implying that the shape of the ore deposit has a first-order control on the P-wave scattering response. Unlike point diffractors or spherical bodies, dipping lenticular, or ellipsoidal inclusions focus scattered P-waves in the specular direction, that is downdip from the orebody (Eaton, 1999; Eaton et al., 2003). An example of a specular diffraction/reflection generated by approximately 6-8 Mt massive sulfide deposits at about 1.2$\mathrm{km}$ depth is reported in Malehmir and Bellefleur (2009). In favorable situations, small-size massive sulfide deposits of 0.15-0.2 Mt may be detected at shallower depths, as reported by Urosevic et al. (2012).

\section{Surface and borehole acquisition techniques}

Three-dimensional surface seismic surveys are the ideal solution in complex geologic environments such as mining areas. However, mainly due economic restrictions, 2D surveys often are conducted. Main challenges here are the interpretation and processing of 2D seismic data, especially in complex mining areas where the data often are acquired along crooked lines (Wu, 1996; Zaleski et al., 1997; Nedimović and West, 2003). Out-of-the-plane structures typically are present, and these pose challenges in the processing and interpretation of data acquired in mining areas. Figure 3 shows a comparison between a strong seismic anomaly observed in
2D data with that observed in 3D data (see Malehmir et al., 2010). The bright spot observed on the $2 \mathrm{D}$ section is generated by a massive sulfide deposit nearly $700 \mathrm{~m}$ away from the $2 \mathrm{D}$ line. This example demonstrates the benefit of 3D surveys for better delineation of mineral deposits at depth.

Figure 2. Acoustic properties of most common crystalline rocks and ores (modified after Salisbury et al., 2003). Shown also are magnetite and massive sulfide samples from Dannemora and Kristineberg, Sweden (Malehmir et al., 2012a), and massive sulfide samples from Flin Flon, Canada (White et al., 2012).

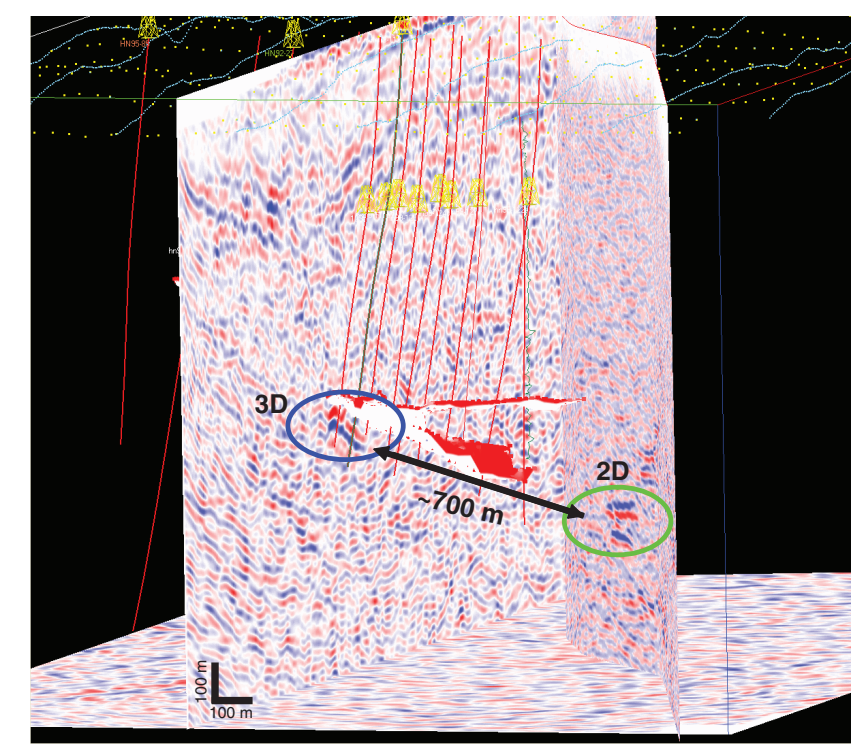

Figure 3. Comparison showing a seismic anomaly observed in $2 \mathrm{D}$ data with its actual location in 3D data (from Malehmir et al., 2010). The seismic anomaly is from an approximately 6-8 Mt massive sulfide deposit known as the "deep zone" at about 1.2-km depth (Matthews, 2002). 
Surface seismic surveys are suitable for mapping gently to moderately dipping reflectors, otherwise downhole surveys are preferable. Downhole seismic surveys such as side scan, VSP and mine seismic profiling (MSP), and in-mine seismic surveys are best suited for imaging steeply dipping to subvertical structures (e.g., Price, 1974; Cosma, 1983; Wong et al., 1983, 1984; Gustavsson et al., 1984; Galperin, 1985; Peterson et al., 1985; Spathis et al., 1985; Harman et al., 1987; Mutyorata et al., 1987; Duncan et al., 1989; Juhlin et al., 1991; Sinadinovski et al., 1995; Frappa and Moinier, 1993; Cao and Greenhalgh, 1997; Greenhalgh and Bierbaum, 1998; Urosevic and Evans, 2000; Greenhalgh et al., 2000, 2003; Wong, 2000; Adam et al., 2003; Cosma et al., 2003, 2007; Perron et al., 2003; Bellefleur et al., 2004a, 2004b; $\mathrm{Xu}$ and Greenhalgh, 2010). They have typically higher resolution than surface seismic data, which make them attractive for delineating fracture and fault zones for mine planning or as a complement to surface seismic surveys. In addition, they allow direct estimation of the medium velocity, which is required for prestack time/depth migrations. An extensive program of seismic investigations for geophysical delineation of subvertical diamond-bearing kimberlite pipes was conducted at Diavik in the Northwest Territory of Canada during the years 2004-2006 (Cosma and Enescu, 2011). Figure 4 shows an example of side-scan (see Zheng and Stewart, 1997) data that clearly allows the geometry of a kimberlite pipe in 3D. After processing, the migrated seismic profiles were integrated with pipe models, using all available information, to honor geologic data from boreholes (pierce points). Examples of successful downhole imaging for exploration and mine planning are provided by Mueller et al. (2012) and Wood et al. (2012), respectively. For example, Wood et al. (2012) show how steeply dipping reflections from faults can be mapped closer to the surface on VSP data than on surface seismic data, an important outcome that was critically important for mine planning at the Millennium uranium deposit, northern Saskatchewan, Canada. Urosevic and Evans (1998) use a combination of surface and downhole seismic reflection techniques to characterize a thin kimberlite pipe in the Northern Territory, Australia.

\section{Processing considerations}

In most hard-rock environments, the seismic velocities $(>5.5 \mathrm{~km} / \mathrm{s})$ and densities $\left(>2650 \mathrm{~kg} / \mathrm{m}^{3}\right)$ of rocks are higher than those commonly encountered in conventional seismic exploration for hydrocarbons, and this has to be taken into account during acquisition and processing. Reflections often are reliably observed, even though the reflection coefficients are relatively low because attenuation also generally is low. Very few multiple reflections appear to be present on the records in spite of clear primary reflections. Small reflection coefficients and the fact that there is no general decrease in reflection amplitude due to attenuation (apart from the geometrical spreading) with depth, in contrast to the situation generally found in young sedimentary basins, best explain this observation. An alterative explanation also is that the absence of detectable multiple reflections in many situations is due to the lowreflection coefficients, which result in multiple reflections below the noise threshold. Ground-roll velocity often is high (about $3000 \mathrm{~m} / \mathrm{s}$ with a dominant frequency of $10-15 \mathrm{~Hz}$ ) where Precambrian strata outcrop, and consequently, vibrator and geophone arrays do not always suppress ground-roll effectively. However, ground-roll can often be suppressed by simple temporal filtering or the application of various multichannel filters to help preserve the signal bandwidth. Lastly, the normal moveout on the common midpoint gathers is small due to the high velocities, restricting the sensitivity of velocity analysis. Because most geologic targets have small dimensions, processing methods should aim at preserving the potential diffraction signals from these targets. Therefore, prestack dip moveout (DMO) along with poststack migration algorithms still may be more useful in hard-rock data processing and mining applications than prestack migration (e.g., Adam et al., 2003).

\section{CASE HISTORIES: PAST AND PRESENT}

Here we present past and current research activities on the use and implementations of seismic methods for mineral exploration and mine planning. Seismic methods have been used with different a)

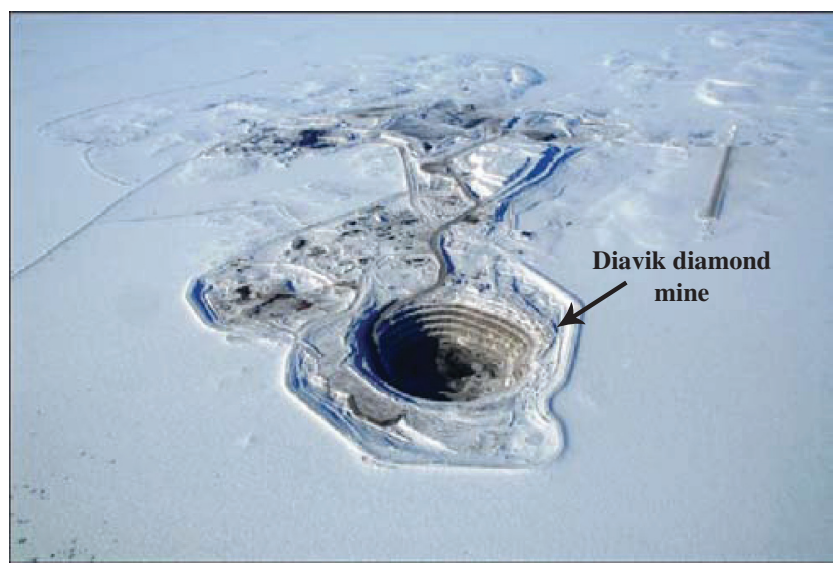

b)

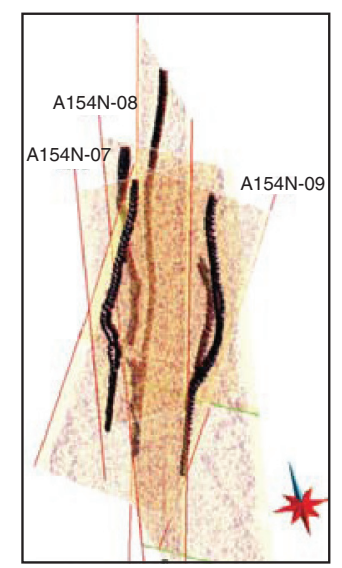

c)

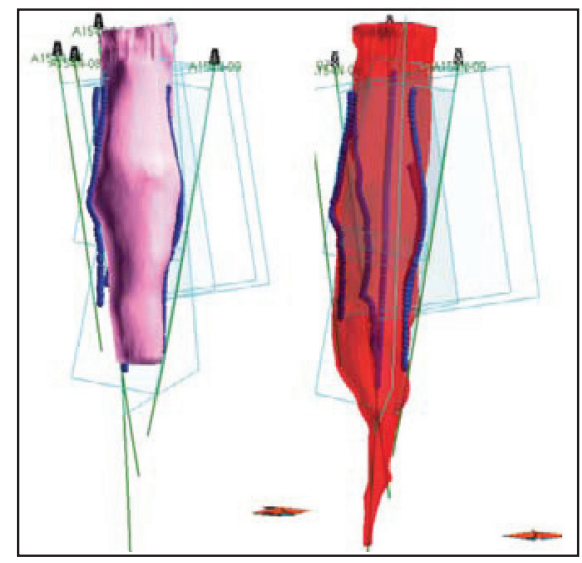

Figure 4. (a) Aerial photo from Diavik diamond mine in Northwest Territory of Canada. (b) Seismic interpretations highlighting the shape of the kimberlite pipe from four boreholes around the pipe. The irregular shape of the pipe may generate superposed reflections arriving from different azimuths with slightly different time functions. It is not evident which of these reflection events lay exactly in the imaging plane and thus, an allowance for this ambiguity has been made. The more regular the shape of the pipe, the less ambiguity. (c) Reshaping of the pipe model based on the interpretations from the seismic side scans, shown in blue lines. Initial model is shown on the left and final model on the right. Figure is provided by Vibrometric (also see Cosma and Enescu, 2011). 
success and extent in different regions and this is somewhat reflected in the following summaries. Application of seismic methods for mineral exploration first became established in South Africa, and later extensively developed in Canada and to some extent to Australia, before being implemented on a larger scale in Europe.

\section{Australia}

Geoscience Australia has been a leading organization in Australia with more than 40 years experience in land seismic surveys and has acquired more than $15,000 \mathrm{~km}$ of deep land crustal seismic reflection data (see www.ga.gov.au) and numerous 2D seismic refraction profiles (Figure 5). Many of these surveys cross major mineral provinces of Australia such as Mount Isa and the mineral provinces of the Yilgarn craton. Some major and recent seismic programs by Geoscience Australia, together with its partners, are the onshore energy security program (OESP), AuScope, and the Research Facility for Earth Sounding (ANSIR). For example, a deep seismic reflection survey recently acquired across major gold producing regions of southeast Australia provides important insights into the crustal-scale fluid pathways and possible source rocks for the mineral deposits (Willman et al., 2009). The seismic data show that the areas with the greatest gold endowment lie above lower crustal regions that have preserved the thickest succession of "fertile" mafic igneous rocks in zones up to about $25 \mathrm{~km}$ thick (Willman et al., 2009). Moreover, the seismic data show that the transition from predominantly shallow- to steeply dipping fault segments occurs in the middle-to-upper crust near the boundary between thick imbricated meta-volcanic rocks that lie immediately below 6 to $15 \mathrm{~km}$ of folded meta-sedimentary rocks. Willman et al. (2009) conclude that this transition might have coincided with fluid escape zones that aided the transfer of permeability away from first-order faults and into the overlying fold dominated turbidites.

Figure 6 clearly demonstrates how major discoveries in recent years have trended toward greater depth in Australia (Schodde, 2011), although shallow deposits still are being discovered. Curtin University, forecasting the need for deep geophysical methods capable of delineating mineral deposits at depth, initiated an experimental program in 2004 consisting of high-resolution seismic reflection surveys across six mine sites to image complex structures hosting gold deposits in the depth range 100-1500 m (Urosevic et al., 2005, 2007). Several major mineral exploration companies supported the program through the Western Australian Government via the Minerals and Energy Research Institute of Western Australia (MERIWA). Prior to this program, in 2002, several low- and high-resolution seismic lines were reprocessed and reanalyzed in the Kambalda, a major gold field region about $60 \mathrm{~km}$ from the mining city of Kalgoorlie in Western Australia, which allowed high-quality seismic images of structures hosting gold mineralization to be investigated (Urosevic et al., 2007). This led to the acquisition of approximately $150 \mathrm{~km}$ of new high-resolution seismic data in 2004. Initial results of this study were summarized in Urosevic et al. (2005). The most extensive component of this program included seismic test surveys over the Kambalda dome that hosts numerous gold and massive sulfide deposits. The project was preceded by several pilot studies, which involved reprocessing, and reanalysis of regional seismic data acquired in 1999 by Geoscience Australia. The most important 2D seismic line, termed Victory because it passed near the Victory mine site, was acquired in 2002 (Figure 7). This survey was acquired with a close source/ receiver spacing of only $10 \mathrm{~m}$ in contrast to previous regional

Figure 5. Regional seismic reflection and refraction surveys carried out by Geoscience Australia (Courtesy of Geoscience Australia).

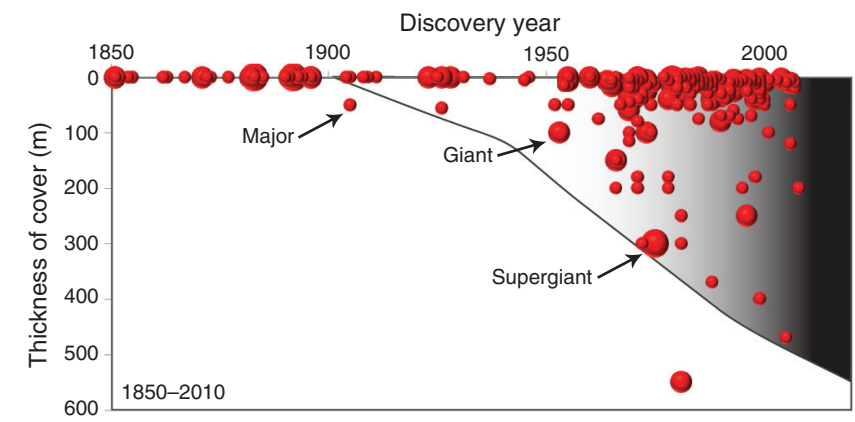

Figure 6. Thickness of cover for major mineral discoveries (bulk minerals such as coal, bauxite, and iron ore are excluded) in Australia between 1850-2010 clearly indicating a trend toward depth (Schodde, 2011) while still shallow deposits are found. Major defined as $>1$ million ounce $\mathrm{Au},>100 \mathrm{kt}, \mathrm{Ni},>1 \mathrm{Mt} \mathrm{Cu}$. Giant is $>5 \mathrm{Mt} \mathrm{Cu}$-equivalent and Supergiant $>25 \mathrm{Mt} \mathrm{Cu}$-equivalent. 
surveys that utilized $40 \mathrm{~m}$ receiver spacing and $80 \mathrm{~m}$ shot spacing. Highly encouraging results were obtained in 2004 after reprocessing and reanalysis of the Victory seismic line (Stolz et al., 2004; Urosevic et al., 2005, 2007). Vast improvements of the quality of seismic images were obtained through computation of accurate weathering statics, several passes of constant velocity scans, DMO corrections, and post- and prestack depth imaging, constrained by the known geologic structures. The images were used to analyze the orientation and extent of known thrusts.

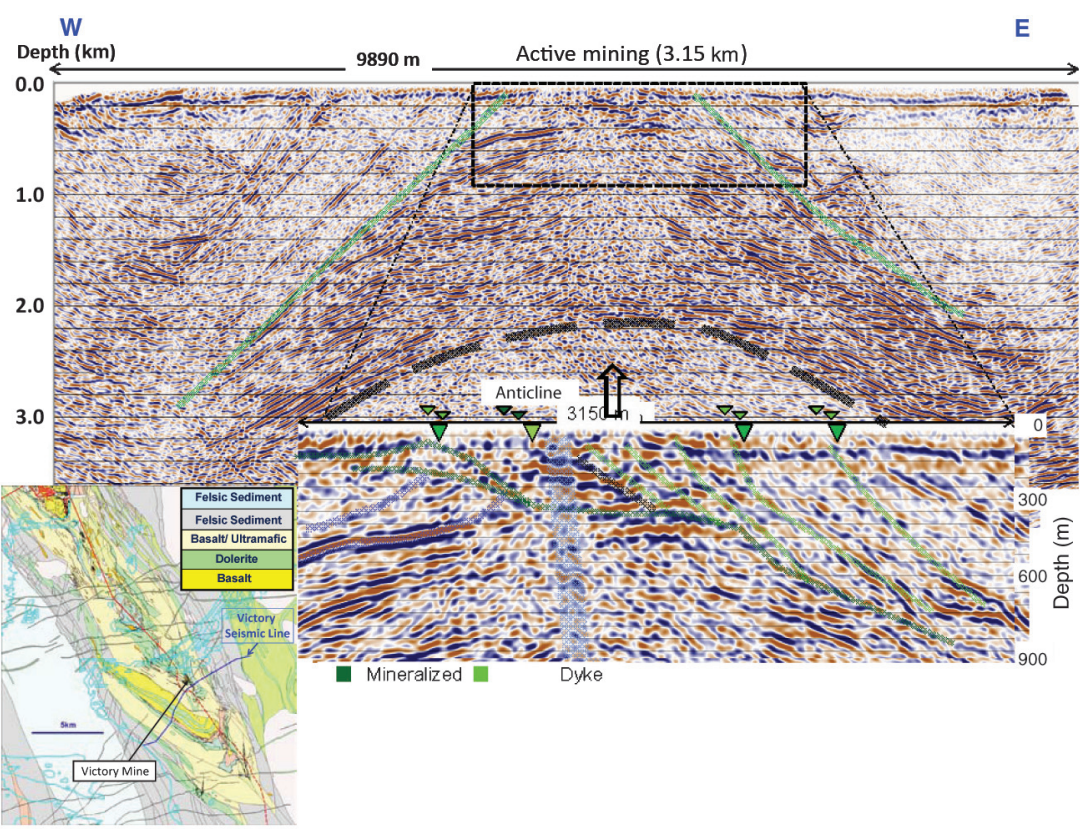

Figure 7. Geologic map of the Kambalda anticline (inset map). Blue line in the inset shows the trace of the Victory seismic line, red is the main strike line recorded along the crest of the anticline. Depth-migrated Victory seismic line. Large anticline (gray dashed line) underlines the greenstone packet, which is bounded by large thrusts: Foster thrust (west) and Bolder Lefroy (east) are labelled with green transparent lines, top display. An enlarged part of the line within the black rectangle as marked in the top display is shown below. This part of the seismic line passes close to four existing mine sites. Mineralized structures are shown in light green, dark green is the gold occurring in relation to one of the stratigraphic markers. Courtsey of Gold Fields.

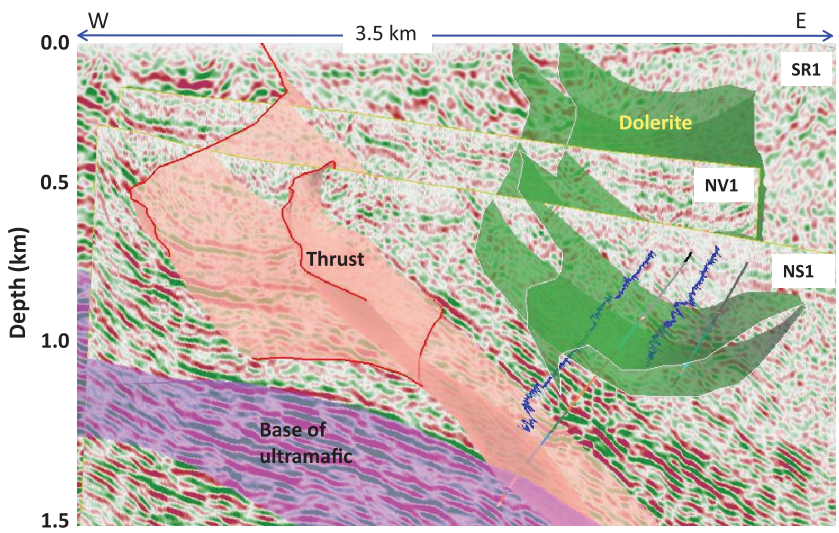

Figure 8. Three high-resolution seismic lines acquired across the central part of St. Ives mine camp. Seismic images integrated into the mine plan show main structural features of interest to gold exploration. See text for detailed description of the figure. Courtesy of Gold Fields.
Subsequently it was realized that smaller scale structures also could be identified in the data (Figure 7).

Encouraged by this result, 17 additional lines were recorded over the Kambalda dome during 2004 within the program. Comprehensive data analysis followed that included integrating data from regional logy, logging, potential field modeling, and the reflection seismic surveys. New exploration strategies were developed using the seismic images to produce accurate structural models. Figure 8 shows an example of successive high-resolution seismic lines integrated into mine scale geology across a central zone of the St. Ives gold mine camp. Important gold mineralization zones are associated with seismically reflective shear zones along normal and relaxation faults (Urosevic et al., 2007). After these successes, seismic exploration of the Yilgarn craton accelerated and the MERIWA project evolved into a larger research program named the Centre of Excellence for High-Definition Geophysics (CHDG) that was sponsored by the state government and supported by industry via targeted research grants.

Initial 2D seismic images obtained under the program further demonstrated that reflection seismic data were of great value to the mining industry and allowed the research program to expand from basic 2D field trials at an experimental level to 3D seismic surveys, the method of choice for precise targeting of the extensions of existing deposits and mapping new mining targets. To date, a significant number of 3D seismic surveys have been conducted in the Kambalda region for Consolidated Minerals, Independent Group, Mincor, BHPB Nickel West, and a wider area such as Weebo Well (Poseidon Nickel), Spotted Qual (Newexco), Geraldton area, Golden Grove, Oxiana 3D (MMG), Pilbara region (Rio Tinto), and Ranger (ERA). Several 3D surveys were conducted for nickel exploration in the Kambalda region with great success (Urosevic et al., 2008). Urosevic et al. (2012) show an example of results from a 3D survey conducted over massive sulfide deposits in the Kambalda region with volumetric interpretation, enabling the precise mapping of the key ultramafic-basalt interface where most of the Ni-sulfide deposits are found.

Within the CHDG program, the research diversified in the types of mineral deposits to be targeted (gold, nickel, diamonds, uranium, copper, zinc, and iron ore) and now under the Deep Exploration Technologies Cooperative Research Centre (DETCRC) the focus is on advancing in general the application of seismic methods for mineral exploration in the hard-rock environment.

\section{Canada}

Several publications summarize the application of seismic reflection methods for mining exploration in Canada. In particular, Eaton et al. (2010) present a comprehensive overview of the work undertaken during the Lithoprobe program, a national research project that combined multidisciplinary Earth science studies of the Canadian landmass and surrounding offshore margins (also see Clowes et al., 1984). Lithoprobe was instrumental in establishing 
acquisition, processing, and interpretation approaches suitable for the hard-rock environment that is typical to several volcanogenic massive sulfide mining camps across Canada. This includes the Bathurst (Salisbury et al., 1997), Buchans (Spencer et al., 1993; Wright et al., 1994), Manitouwadge (Roberts et al., 2003), Matagami (Milkereit et al., 1992a; Adam et al., 1996, 1998, 2003; Calvert and Li, 1999), Noranda (Adam et al., 1992; Verpaelst et al., 1995; Perron and Calvert, 1998), Selbaie (Milkereit et al., 1992b; Perron et al., 1997), Sudbury (White et al., 1994; Wu et al., 1995; Adam et al., 2000; Milkereit et al., 2000), and Thompson (White et al., 1997, 2000) mining camps. During Lithoprobe, seismic reflection methods were proposed as a deep exploration tool that could improve the knowledge of structures and stratigraphy in existing mining camps, but also to provide drilling targets at depths beyond those achieved with conventional geophysical mining methods.

Several Canadian mining companies were active partners of the Lithoprobe initiative, and some continued to use and develop seismic methods for their exploration projects. For example, Noranda Inc. (now Xstrata) acquired several post-Lithoprobe 2D and 3D seismic data sets for VHMS exploration in the Bathurst and Abitibi mining camps. One of the best-known surveys acquired by Noranda is the Halfmile Lake 3D survey (New Brunswick) that led to the discovery of a 6-8 Mt massive sulfide lens at a depth of $1.2 \mathrm{~km}$ (Figure 9; Salisbury et al., 2000; Matthews, 2002; Malehmir and Bellefleur, 2009). Similar 3D surveys in the Sudbury complex also were successful in delineating massive sulfide deposits (see Milkereit et al., 2000). Figure 10 shows examples of 2D and 3D surveys over one of the Sudbury Ni-Cu-PGE deposits. Noranda and Aur Resources Inc. (now Teck Cominco) also partnered in the acquisition of the Louvicourt 3D survey near Val d'Or where the joint use of surface seismic data and borehole EM data identified an extensive zone of dissemi- nated sulfides (Adam et al., 2007). Some of the data and results from Noranda's work were not publicly released, but are now being revisited. Malehmir and Bellefleur (2010) and Cheraghi et al. (2011, 2012) summarize the results of $2 \mathrm{D}$ and $3 \mathrm{D}$ seismic profiles acquired by Noranda Inc. near the Brunswick No. 6 mine in a highly folded and deformed area characterized by steeply dipping stratigraphy. Results show successful imaging of the steeply dipping stratigraphy, including a group of reflections containing one of the key mineralized horizons (e.g., the Brunswick horizon). Bellefleur et al. (personal communication, 2012) present 2D seismic data from the Noranda mining camp (Québec), demonstrating that prospective exhalative horizons (chemical sedimentary rocks, usually containing oxide, carbonate, or sulfide as anions, and iron, magnesium,

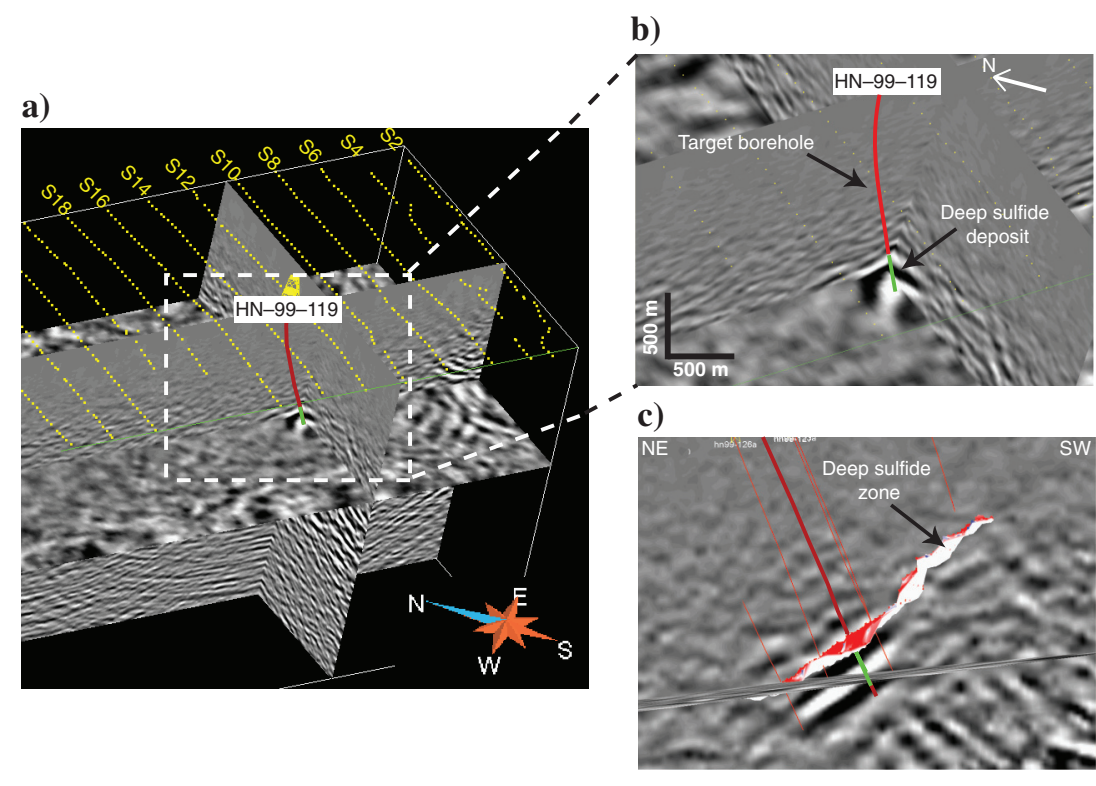

Figure 9. (a)-(c) Composite 3D perspective views from migrated slices, showing how high amplitudes in the seismic data correlate with the location of a deep massive sulfide deposit at $1.2 \mathrm{~km}$-depth in the Halfmile Lake area. Solid green line in (a)-(c) marks the intersection of discovery borehole HN-99-119 with the deep massive sulfide zone. $V=H$. Figure is modified from Malehmir and Bellefleur (2009). a)

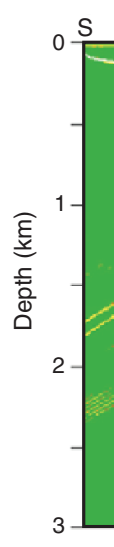

b)

$\mathrm{N} / \mathrm{S}$ c)

Figure 10. (a) Synthetic seismic section and (b) real seismic section demonstrating that the back-filled (white zone in [a]) part of a small massive sulfide orebody (red zone in [a]) is expected to generate a strong diffraction seismic signal (Milkereit et al., 1996). (c) Depth slice from a 3D seismic survey in the Sudbury area shows the diffraction signature of the orebody and its back-filled part (Milkereit et al., 2000). 
base metals, and gold formed by the issuance of volcanically derived fluids onto the sea floor or into the sea), can be detected with seismic methods. The contrast of acoustic properties between andesite and rhyolite units located on each side of exhalite produces seismic reflections.

Seismic reflection methods also have been used for diamond exploration or delineation of diamond-bearing formations in several locations in Canada. In the Northwest Territories, a 2D seismic survey conducted across the De Beers Snap Lake mine produced images that tracked a 2-3-m-thick diamondiferous dike in crystalline rocks from the near surface to depths greater than $1300 \mathrm{~m}$ (Hammer et al., 2004). In the Fort à la Corne kimberlite field of central Saskatchewan, seismic surveys have been conducted in a much different geologic setting. There, the diamondiferous kimberlites are intruded and interstratified with terrestrial and marine sediments. Two-dimensional surveys, reported by Gendzwill and Matieshin (1996), White et al. (2007), and White and Kjarsgaard (2012), were able to delineate the various volcanic/sedimentary facies, offsetting and, in some cases, the underlying feeder vents. In a comparable setting, VSP surveys conducted at the Victor mine near Attiwapiskat, Ontario, and at the Diavik mine in the Northwest Territories were used to trace the vertical sidewall of kimberlite pipes (Bellefleur et al., 2004a; Cosma and Enescu, 2011).

Seismic exploration for uranium deposits in Canada has focused on the Athabasca basin of northern Saskatchewan and Alberta. Seismic methods are well-suited to exploration in this setting as the uranium deposits typically occur near the unconformity that separates an undeformed clastic sequence from underlying metamorphic crystalline basement rocks. As summarized by Hajnal et al. (2010), the first successful demonstration of high-resolution seismic methods during the Lithoprobe project spawned several subsequent 2D exploration surveys at Shea Creek in 1997, McArthur River in 2004 (e.g., Gyorfi et al., 2007; White et al., 2007), Russell and Moore Lake in 2004-2005, and Midwest Northeast and Millennium 3D surveys in 2007 (e.g., Juhojuntti et al., 2012; Wood et al., 2012). Hathor Resources performed the first seismic-based major uranium discovery in 2007 , leading to a 2010 total resource of 12.1 million pounds of $\mathrm{U}_{3} \mathrm{O}_{8}$.

Canadian mining camps often are characterized by steeply dipping stratigraphy that is sometimes difficult to image with surface acquisition geometries. As discussed earlier, borehole seismic imaging often is more appropriate than surface methods in such steeply dipping environments for providing images of the stratigraphy, structures, and orebodies. Borehole seismic surveys were acquired in the Sudbury, Abitibi, and Bathurst mining camps (Eaton et al., 1996; Adam et al., 2003; Perron et al., 2003; Mueller et al., 2012). Part of this work was carried out by the Downhole Seismic Imaging (DSI) consortium created in the late 1990s by Falconbridge, Inco, Noranda, Quantec Geoscience, and the Geological Survey of Canada to assess the usefulness of downhole seismic methods for exploration of massive sulfide deposits in steeply dipping stratigraphy. DSI data acquired over the Halfmile Lake deposit (Bellefleur et al., 2004b) identify a complex scattering response from a deep sulfide lens $(1.2 \mathrm{~km})$ that included P-P, P-S, S-P, and S-S waves, demonstrating that mode-converted and shear waves also are valuable signals to record for mineral exploration. At the ore scale, crosshole seismic surveys were used successfully to delineate mineralization and estimate grades. Cosma and Enescu (2003) and Perrozi et al. (2012) present case studies from the Voisey's
Bay nickel deposit, Labrador, in this respect. Hurich and Deemer (personal communication, 2012) report one of the first applications of seismic interferometry for mineral exploration, which combines surface and borehole imaging at Voisey's Bay. Their approach is supported by physical rock property measurements showing that the choice of a suitable seismic imaging method can vary spatially according to compositional variations within a deposit (Duff et al., 2012).

Recent developments in Canada include the utilization of multicomponent seismic data for VHMS and gold exploration. For example, Snyder et al. (2008) present 2D multicomponent highresolution data acquired in the Timmins mining camp, Ontario, as part of the Discover Abitibi initiative. The processing of horizontal components following P-S conversions clarified the interpretation of faults and lithologies that were imaged previously on vertical component data. Malinowski et al. (2011) present P-S converted wave imaging of 2D seismic data acquired in the Flin Flon mining camp, Manitoba. The P-S images provide complementary information to conventional P-P images, including a prominent P-S reflection associated with the ore zones. Snyder et al. (2008) and Malinowski et al. (2011) determine that $V_{\mathrm{P}} / V_{\mathrm{S}}$ or Poisson's ratio derived from $3 \mathrm{C}$ data could help discriminate lithologies in the mining environment. New 2D and 3D results from the Flin Flon mining camp are presented by White and Malinowski (2012), White et al. (2012), and Malinowski et al. (2012). However, more work is required to understand all the benefits of using nonconventional wave-modes in mineral exploration (Bellefleur et al., 2012).

\section{Europe}

Application of seismic methods for mining purposes in Europe is widespread. One of the earliest seismic surveys in a hard-rock environment was carried out in 1927 to investigate ore deposits near Krivoy Rog (Karaev and Rabinovich, 2000). In the 1940s, refraction seismic technology was used to study the crystalline basement of the former Soviet Union (Gamburtsev et al., 1952; Sharov, 1997; Karaev and Rabinovich, 1995). High-frequency seismic methods were first attempted in the mid-1950s to image mineral deposits and map vertically layered structures (Berson, 1957). Numerous papers on the correlation between seismic velocities and physical parameters of mineral deposits were published subsequently (Dortman and Magid, 1969; Krylov et al., 1990). By the late 1980s, several case studies documenting the potential of seismic techniques as a mapping tool in the hard-rock environment had been performed. Figure 11 shows results from a VSP investigation in the Kola Peninsula, Russia, of a mafic-ultramafic intrusion containing nickel mineralization (Shopin, 1981). As evident on Figure 11, the VSP data clearly image the mafic-ultramafic layers that host the major nickel mineralization. From the available Russian literature, it appears that a large number of mineral deposits, such as nickel, zinc, copper, and uranium, were discovered using reflection seismic methods during the Soviet period in various regions such as in the Ural Mountains, in Kazakhstan, in the Baltic Shield region, and in Eastern Siberia. However, today there are few reports on the use of seismic methods for mining applications in Russia.

In contrast, in the western and central parts of Europe, especially in Finland and Sweden, several published accounts of using highresolution seismic methods for mineral exploration and site characterizations have been reported recently (e.g., Juhlin and Palm, 1999; Cosma et al., 2003; Malehmir et al., 2006, 2007, 2009a, 
2009b; Tryggvason et al., 2006; Schmelzbach et al., 2007). In Finland, the Finnish reflection seismic experiment (FIRE, 20012005) and high-resolution reflection seismics for ore exploration (HIRE, 2006-2010) projects acquired more than $2000 \mathrm{~km}$ of high-resolution reflection seismic data, large portions of which were over major mining regions (Kukkonen and Lahtinen, 2006; Kukkonen et al., 2011a). For example, during the HIRE project, 15 exploration and mining camps in a diverse selection of geologic environments containing $\mathrm{Cu}, \mathrm{Ni}, \mathrm{Cr}, \mathrm{PGE}, \mathrm{Zn}$, and $\mathrm{Au}$ deposits were surveyed using a network of 2D seismic lines (Kukkonen et al., 2011b). Figure 12 shows an example seismic section of data acquired over the Outokumpu mineral deposits. These seismic data provided the motivation for a deep-drilling program at the Outokumpu site (Kukkonen et al., 2011b). Kukkonen et al. (2012) present an overview of these results with focus on the exploration implications of their seismic images. In particular, a strong reflection imaged by their seismic data is associated to a massive sulfide mineralization, requiring further investigations. Fracture zones also are well imaged in the seismic data. In Sweden, initial successful imaging of faults and fracture zones within Precambrian crystalline rocks was driven by experimental surveys for mineral exploration and the characterization of radioactive waste storage sites (e.g., Juhlin et al., 1991; Juhlin, 1995). This early successful high-resolution seismic reflection work by Juhlin et al. (1991), allowing imaging of fracture zones and lithological contrasts (Figure 13), paved the way for two larger projects in Sweden to study large-scale structures hosting mineral deposits, namely GEORANGE3D (e.g., Malehmir et al., 2006, 2007, 2009a, 2009b; Tryggvason et al., 2006; Hübert et al., 2009) and VINNOVA4D (Dehghannejad et al., 2010, 2012a, 2012b; Skyttä et al., 2010; Bauer et al., 2011). These projects were of a multidisciplinary nature and allowed the construction of a 3D geologic model of a major mining district of northern Sweden. Figure 14 shows results from a high-resolution seismic profile acquired near the Kristineberg massive sulfide mine (Dehghannejad et al., 2010), suggesting the continuation of the orebody at a moderate dip toward the west. Earlier seismic profiles collected in the area (Tryggvason et al., 2006; Ehsan et al., 2012) did not provide the detailed images of the struc-

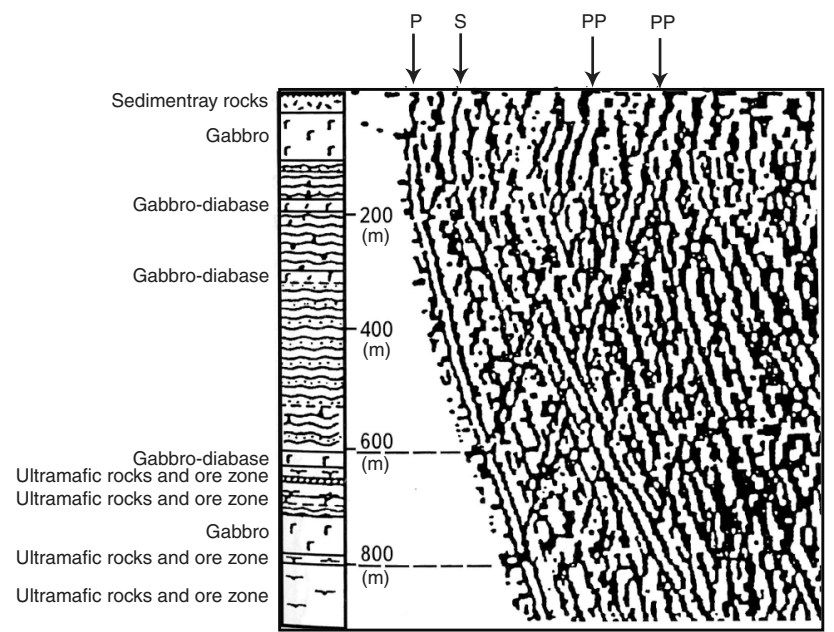

Figure 11. VSP survey in the Miron nickel deposit in the Kola Peninsula, Russia, clearly showing reflections associated with ultramafic rocks at about $600-800 \mathrm{~m}$ depth that host main nickel mineralization in the site (modified after Shopin, 1981). tures as provided by this high-resolution seismic survey. In a different location in Sweden, Malehmir et al. (2011) report on an attempt at 3D seismic imaging of an iron ore mineralization using data from a crooked 2D seismic profile acquired near the Dannemora iron ore mine in central Sweden. Clear reflections from known deposits suggested that the iron ore deposits also could be imaged using surface seismic methods. The seismic velocity and density of the iron ore is shown on Figure 2 (see Malehmir et al., 2012b). Results from two

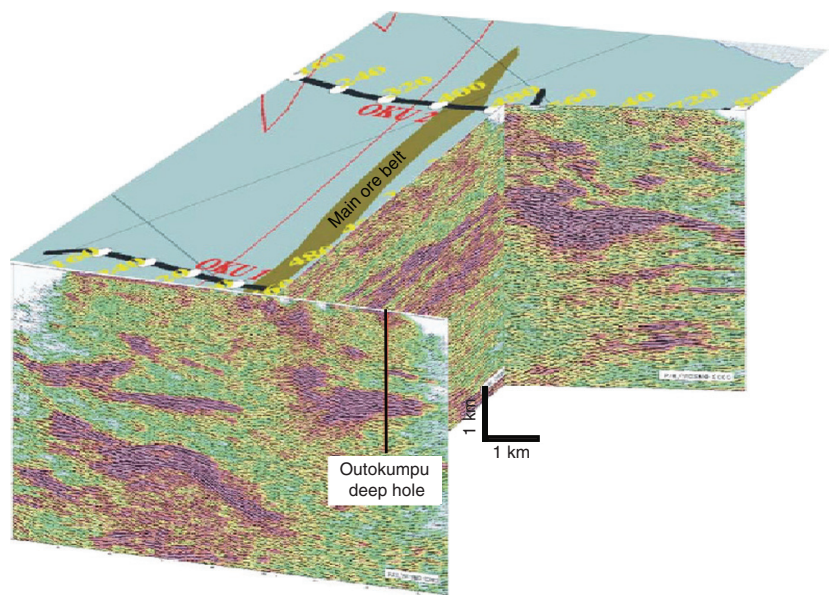

Figure 12. Seismic surveys over the Outokumpu massive sulfide deposits in Finland were used to plan an about 2.4-km-deep borehole in the area (Kukkonen et al., 2011a). Strong reflections intersecting the borehole were found to be from major fracture zones and an ophiolite unit known to host the massive sulfide mineralization. The color scale behind the traces is amplitude envelope showing the higher energy reflectors in red in the seismic sections.

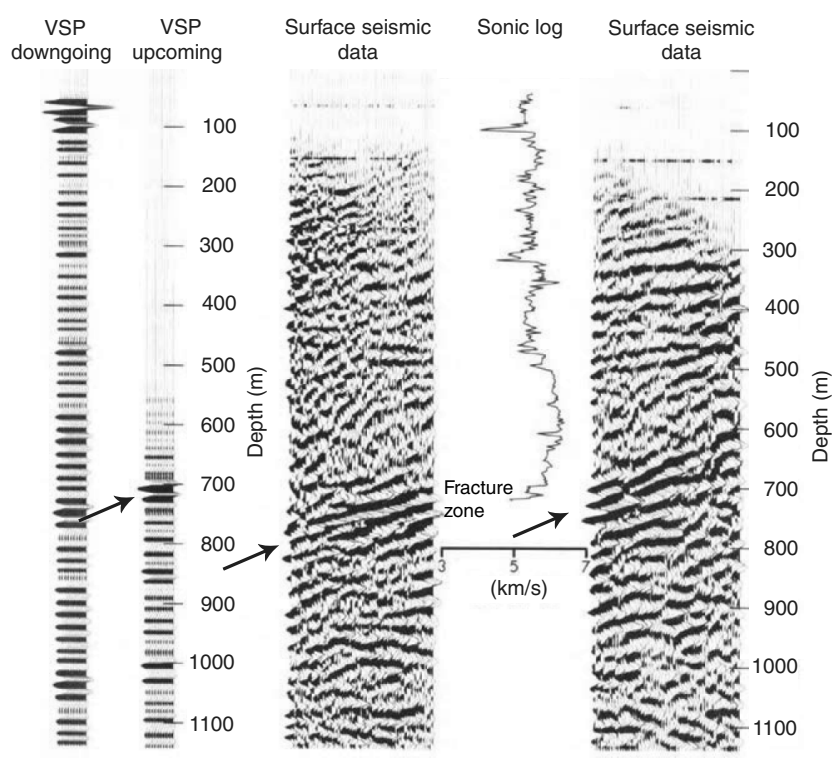

Figure 13. An example VSP survey integrated with surface seismic and borehole sonic measurements in Sweden showing strong reflections marked by arrows (e.g., at $700 \mathrm{~m}$ depth) are generated from fracture (alteration) zones within the granitic basement (modified from Juhlin, 1991). 
high-resolution reflection seismic profiles near the Kiruna mine in northern Sweden are presented (Jensen et al., personal communication), suggesting the continuation of this world-class orebody to depths greater than $2 \mathrm{~km}$.

Three-dimensional seismic surveys in Europe until recently were limited to site characterizations related to nuclear-waste storage locations (e.g., Schmelzbach et al., 2007). Three-dimensional reflection seismic surveying for mining applications now is becoming increasingly common in Europe with a recent survey in northern Finland over a nickel deposit (Koivisto et al., 2012; Malehmir et al., 2012b). This survey was conducted for mine planning and deep exploration. Integration of the results with VSP data allowed for imaging of steep to near-vertical faults that are important for deep mine planning. A seismic exploration target also was drilled and intersected a sequence of sulfide mineralizations in a depth range between 400 to $800 \mathrm{~m}$. More recently, two large 3D seismic surveys were acquired in Portugal and Ireland. These surveys aimed at increasing the knowledge on the continuation of existing massive sulfide deposits to deeper levels and at potentially introducing new exploration targets at depth near existing mines. In the case of Portugal, the 3D survey was motivated by a nearly 30 -years-old seismic profile of very low fold data that showed a strong reflection associated with an existing massive sulfide body (D. West, personal communication, 2011).

\section{Africa}

Prospectors discovered rich deposits of diamonds and gold in southern Africa in the latter half of the nineteenth century, which gave rise to an industry that soon became a cornerstone of the economy. During the twentieth century geophysical methods were used to search for new ore bodies. In the 1980s, reflection seismic surveying was first used to explore for gold in the hard-rock environments. It was soon applied to exploration for platinum, base metals, and coal. Reflection seismics have since become a standard tool for mineral exploration and mine design in southern Africa. Here, we briefly report some of the most well-known examples from the Witwatersrand Basin and Bushveld Complex, and later briefly present

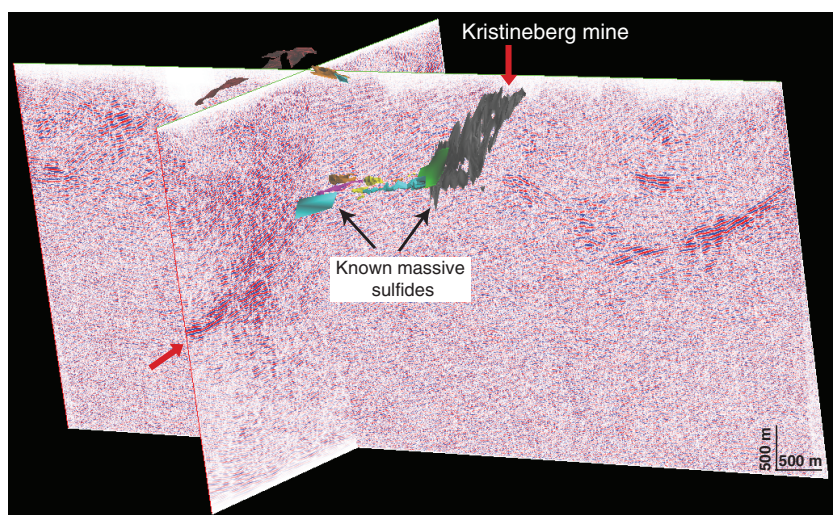

Figure 14. Three-dimensional view showing two recent high-resolution reflection seismic profiles acquired over the Kristineberg massive sulfide deposits (from Dehghannejad et al., 2010). A strong set of reflections marked by a red arrow indicates the continuation of existing deposits. Average seismic velocity and density of these deposits are shown in Figure 2. recent work on base metals and diamond exploration as well as those conducted for mine planning.

The Witwatersrand Basin has produced about one-third of the gold ever mined, worldwide. The Witwatersrand basin is Archean in age, and largely covered by younger strata. In the 1930s and 1940s, gravity and magnetic methods were used to discover and develop the Far West Rand, Klerksdorp, and Free State gold fields, and mining soon reached depths exceeding $3 \mathrm{~km}$. However, potential field methods are unable to image the detailed structure of deeply buried strata, and deep drilling is costly and slow. Reflection seismic methods were implemented in the 1980 s, rejuvenating exploration activities and contributing to the discovery of the South Deep orebody (Haslett, 1994) and new resources in the Bothaville Gap (Gray et al., 1994; Tucker et al., 1994). The adaptation of reflection seismic technology to the hard-rock environment over the last quarter century has been described by several authors, e.g., Campbell and Peace (1984), Durrheim (1986), Pretorius et al. (1989), Campbell (1990), Campbell and Crotty (1990), Durrheim et al. (1991), Campbell (1994), De Wet and Hall (1994), Pretorius et al. (1994), Weder (1994), Pretorius and Trewick (1997), Gibson et al. (2000), Stuart et al. (2000), Pretorius et al. (2000), and Gillot et al. (2005). A comprehensive review of the use of reflection seismology to map the Witwatersrand Basin is provided by Pretorius et al. (2003).

Gold was discovered in 1886 in quartz pebble conglomerates that crop out near present-day Johannesburg. As mining proceeded, the dipping "reefs" were found to persist to great depths. The conglomerates (or the reef) had been deposited on the rim of an Archean sedimentary basin, which largely is covered by younger strata. The reefs were traced by geologic inference and geophysical mapping, and new gold fields were discovered in the East Rand district in 1914, the Far West Rand and Klerksdorp districts in 1937, the Orange Free State in 1946, and the Kinross district in 1955. The gold ore bodies generally are thinner than $2 \mathrm{~m}$ and are seismically indistinguishable from the enclosing quartzites. Fortunately, marker horizons with significant seismic impedance contrasts occur within tens to hundreds of meters of the ore bodies. These horizons have been used to image horsts or anticlines that may bring the reefs to mineable depths, and grabens or synclines that may have preserved the reefs from erosion. Anglo American Corporation was the first company to commission a 2D seismic survey in this part of the basin. Between 1983 and 2003, it had acquired more than 16,000 km of 2D data on the Kaapvaal craton and seven 3D surveys to assist gold mine planning and development (Pretorius et al., 2003). JCI Geophysical Unit initiated synthetic seismogram modeling in mid-1982, followed by several test surveys over gold prospects in 1983 (Campbell, 1990). Among the most notable early successes was the delineation of the De Bron fault on the Joel mine lease area in the Free State gold fields. However, 2D seismics could not resolve the structural complexity of JCI's South Deep prospect in the West Rand gold field, and consequently, the first hard-rock 3D seismic survey in South Africa was conducted in 1987 (Campbell and Crotty, 1990). South Deep mine has since come into production. With some 78 million ounces of resources and 29 million ounces of reserves, it is one of the world's greatest gold ore bodies. Figure 15 shows an example seismic section extracted from a 3D seismic cube over the Driefontein Gold mine (one of the deepest gold mines in the Witwatersrand Basin). The two key gold-bearing horizons, the Black Reef Formation and 
Ventersdorp Contact Reef (VCR), are very well imaged by the seismic data. Figure 16 shows an interpreted 3D geometry of how the VCR is offset by a major fault clearly identifiable in the $3 \mathrm{D}$ seismic data.

The Bushveld Complex is estimated to contain about $70 \%$ of the world's reserves of platinum group elements, as well as large reserves of chrome, copper, nickel, and vanadium. The most important ore bodies are the Merensky Reef and the UG2 Chromitite Reef. Following the success of the reflection seismic method in mapping down-dip extensions of Witwatersrand Basin ore bodies, the technology was applied to the Bushveld Complex, and soon proved its worth for exploration and mine planning. Figure 17 shows a long seismic transect over the complex (Campbell, 2011). It clearly shows the potential of reflection seismic methods for imaging of large-scale structures hosting the mineralization in the area, e.g., the UG2 layer. The application of $2 \mathrm{D}$ and $3 \mathrm{D}$ reflection seismics in the Bushveld Complex has been described in the literature and reports (Campbell, 1990; 1994; Durrheim and Maccelari, 1991; Odgers et al., 1993; Davison and Chunnett, 1999; Larroque et al., 2002; Stevenson et al., 2003; Trickett et al., 2005, 2007, 2009). A comprehensive review is published by Campbell (2011).

Reflection seismic data acquired on the surface in the Witwatersrand Basin and Bushveld Complex typically have wavelengths of $60-100 \mathrm{~m}$. Consequently, it is difficult to detect faults with throws less than $20 \mathrm{~m}$. However, displacements of the reef as small as two meters may present difficulties to mining operations. The Deep Mine research program (Durrheim, 2007) sought to develop technologies to map reef displacements exceeding $2 \mathrm{~m}$ within $200 \mathrm{~m}$ of mining. A technology scan indicated that borehole radar and mine seismic profiling (MSP) stood the greatest chances of success (Stevenson et al., 2003). MSP is essentially the application of VSP techniques applied underground in boreholes with arbitrary orientations, including upholes. Sensors are clamped in boreholes and sources (e.g., sledge or pneumatic hammers) deployed in tunnels.

Seismic methods have been applied to map the geology of diamond pipes in South Africa and Botswana. In 2003, side scan sonar was used to map the wall of the Finsch kimberlite pipe in South Africa (Cosma et al., 2007). The measurements were done in a borehole drilled from the country rock into the pipe, intersecting it at a depth of $110 \mathrm{~m}$. A seismic response was obtained at distances of up to $150 \mathrm{~m}$, with the signal energy in the 400-2400 $\mathrm{Hz}$ range, yielding a resolution of better than $1 \mathrm{~m}$. During 2007, several seismic surveys were conducted over the Jwaneng diamond-bearing kimberlite cluster of
Botswana to identify a suitable site for the sinking of a 1000-m-deep ventilation shaft (Mathibele, 2007; Bate, 2011). The seismic surveys included VSP, multioffset VSP, and 10 conventional 2D reflection seismic profiles, each about $1 \mathrm{~km}$ in length.

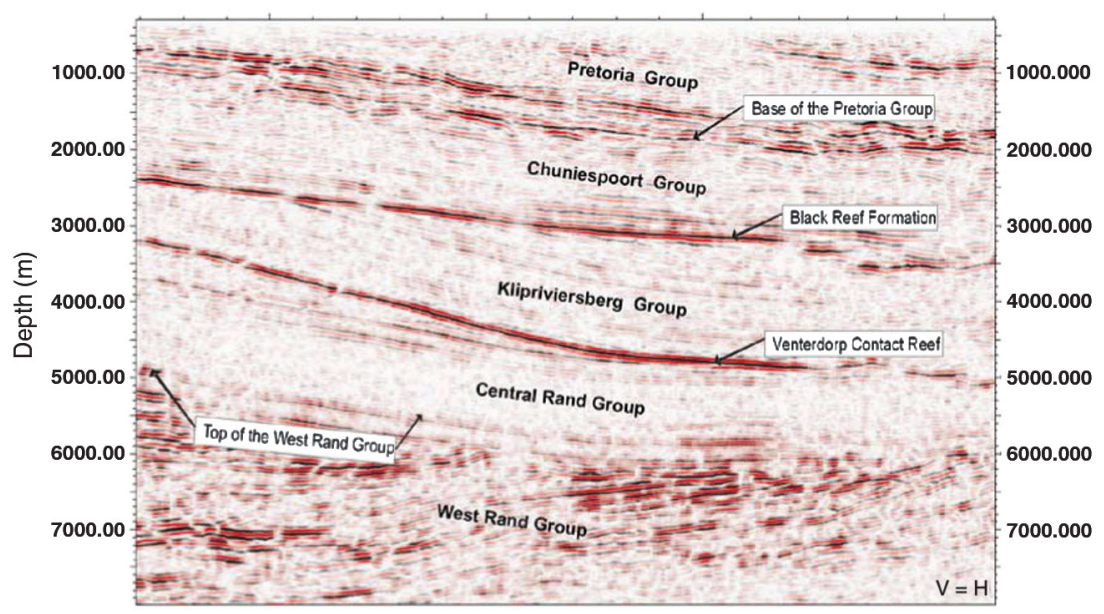

Figure 15. Seismic section extracted from a 3D seismic cube from the Driefontein mine showing successful imaging of the Black Reef Formation (30-m-thick maximum) and VCR, which are two key horizons hosting major gold mineralization in the Witwatersrand Basin. The Ventersdorp Contact Reef (known as VCR horizon) is one of the major gold-bearing horizons in the Witwatersrand Basin and occurs as a distinct horizon (10-100-m-thick conglomerate) between the overlying Klipriviersberg Group lavas $(2714 \mathrm{Ma})$ and the underlying Central Rand Group rocks ( $<2894$ to $>2714 \mathrm{Ma})$. Courtesy of Gold Fields.

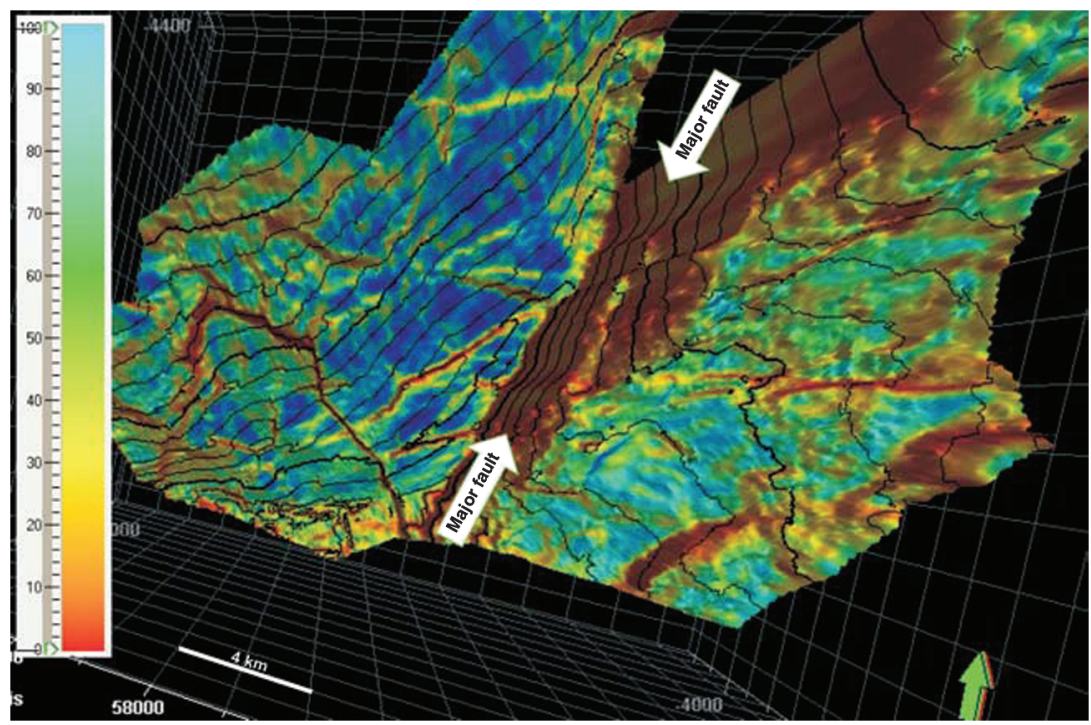

Figure 16. Three-dimensional geometry of the VCR at Kloof and South Deep mines, computed from edge detection seismic attribute (color bar is given in \%, and the arrow points to the north). The north-northeast trending major fault, crosscutting the VCR, is the West Rand Fault which separates Kloof and South Deep mines from the west and east, respectively. The VCR is one of the major gold-bearing conglomerate horizons in the Witwatersrand Basin and occurs as a distinct horizon between the overlying c. 2714 Ma Klipriviersberg Group lavas and the underlying c. 2894-2714 Ma Central Rand Group rocks (see Figure 15). Courtesy of Gold Fields. 
Outside South Africa, Gold Fields conducted a series of reflection seismic surveys in Namibia in support of their exploration and mining activities (Stevenson et al., 2003). One survey was conducted to search for $\mathrm{Pb}-\mathrm{Cu}-\mathrm{Zn}$ ore bodies, where mineralization is controlled by a pipelike paleokarst structure in a moderately folded dolomitic succession. Two ca. $3 \mathrm{~km}$ lines were acquired to search for other paleokarst structures. Although the contact between the dolomitic and underlying clastic strata gave rise to a strong reflection at depths of 200-300 m, no evidence of paleokarst features was found. A similar survey conducted at the Tschudi deposit, $25 \mathrm{~km}$ west of Tsumeb, detected faults that could have been conduits for mineralizing fluids.

\section{LOOKING AHEAD: CHALLENGES AND FUTURE}

Despite the remarkable success of the seismic reflection method in soft rock environments, the mining industry has been reluctant to embrace this technology. Until recently, its needs could be met by traditional methods (electromagnetic, induced-polarization, and potential-field surveying techniques). In addition, seismic methods are relatively costly, the interpretation sometimes is ambiguous, and the performance in hard-rock environments is variable. However, as discoveries of large near-surface deposits are becoming increasingly rare and the reserves of most economic minerals are in decline, it is clear that new deep exploration techniques, such as seismic methods, are required to meet the future needs of industry (Salisbury and Snyder, 2007). Eaton et al. (2003) identify six aspects that need careful consideration when planning a seismic survey. These are (1) acquisition of high-fold data; (2) the need to obtain highfrequency data; (3) forward seismic modeling of mineral deposits; (4) processing considerations with focus on refraction statics, surface-consistent deconvolution, and DMO corrections; (5) physical rock property measurements; and (6) migration considerations. Most of these aspects still require careful consideration when planning; however, the first three generally are given insufficient attention. In addition to these aspects, we present below several areas that need further research and development to enhance the capability of hard-rock seismic methods.

The universal challenge in geophysical methods is how to achieve ever-greater resolution and higher quality data in increasingly complex environments and at greater depths. A step in meeting this challenge recently was taken by field trials of high-resolution vertical seismic profiles (Pretorius et al., 2011). Anglo Platinum developed the method to eliminate geologic surprises prior to shaft sinking. The use of $3 \mathrm{C}$ downhole sensors has two immediate benefits: The travel distance of the reflected wave is reduced, hence, there is less attenuation of the higher frequencies; and S-waves, which travel at about $60 \%$ of the speed of the P-wave velocity and thus have an inherently shorter wavelength, can be used. Pretorius et al. (2011) report that S-wave VSP data give as much as an $80 \%$ improvement in resolution over surface seismic surveys (also see Bellefleur et al., 2004b). However, downhole seismic methods usually are implemented at the development stages or for mine planning. Greenwood et al. (2010) show that hydrophone VSP data can produce high-resolution images, twice as high as those obtained from surface seismic data. The implementation of hydrophone VSP is effective and relatively inexpensive and, hence, makes the use of VSP methods for mining exploration purposes accessible and attractive. With the addition of a baffling system and the use of a close hydrophone spacing, Greenwood et al. (2012) show that hydrophone arrays can be used to create high-resolution images away from a borehole that match the quality of geophone VSP data.

Three-component 3D seismic methods not only have the potential to improve seismic resolution, but also can potentially help to constrain seismic interpretations and may allow the prediction of composition, which is still a challenging topic in hard-rock seismic exploration (see Bohlen et al., 2003; Snyder et al., 2008; Malehmir et al., 2010; Malinowski and White, 2011; Bellefleur et al., 2012). In a similar manner to predictions routinely made in the hydrocarbon industry (i.e., amplitude variation with offset [AVO], elastic and full-waveform impedance inversion), hard-rock seismologists

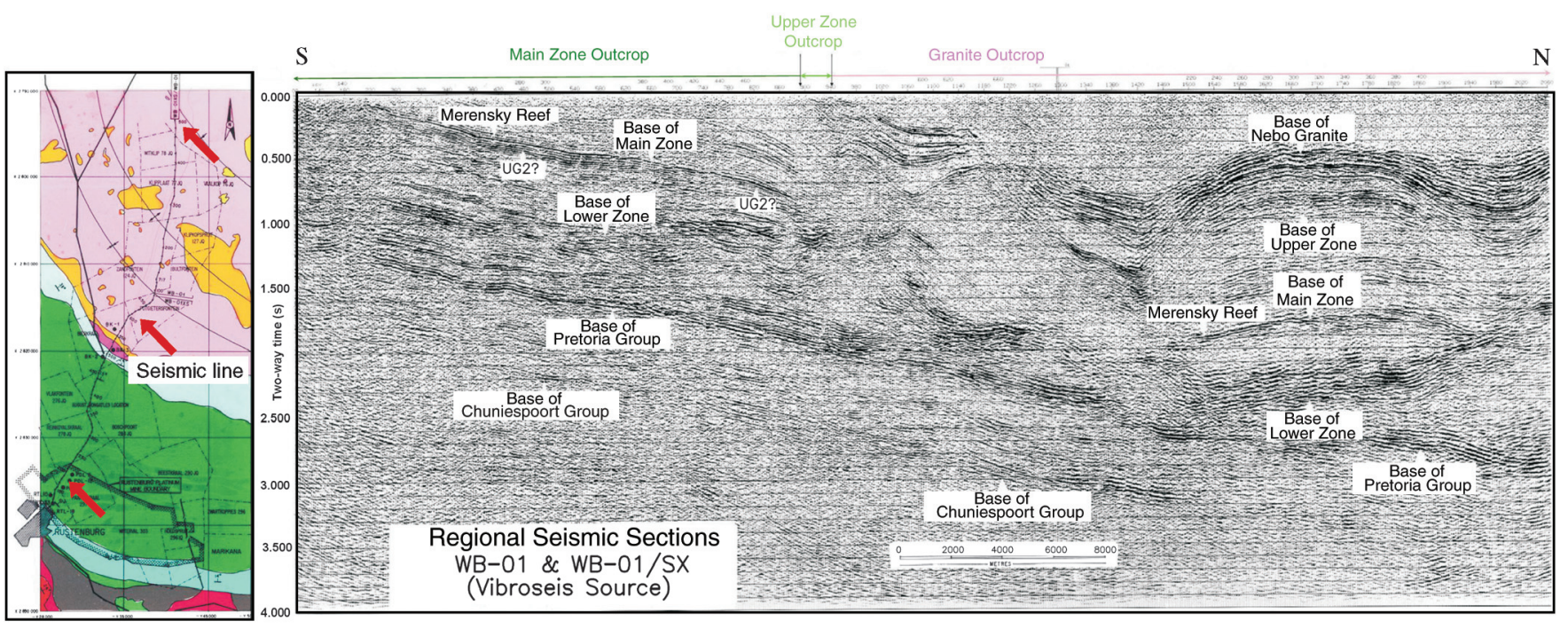

Figure 17. A $50 \mathrm{~km}$ long, N-S vibroseis seismic section extending from northerly dipping $\left(8^{\circ} \mathrm{N}\right)$ Rustenburg Layered Suite (RLS) outcrop near Rustenburg to deep, folded subcrop below Bushveld (Nebo) Granites over the northern sector, highlighting regional-extent magmatic layering and sill-like geometry. The UG2 marker horizon at the top of the RLS Critical Zone is interpreted (this is why it is shown by question mark) to extend down to at least a depth of about $1 \mathrm{~s}$ for about $20 \mathrm{~km}$ downdip from outcrop. Vibroseis linear sweep of 20-90 Hz and geophone and shot spacing of $50 \mathrm{~m}$ were used (modified from Campbell, 2011). Courtesy JCI Ltd. 
should aim at providing information on the potential composition of seismic targets prior to any drilling. However, several challenges need to be overcome before such predictions can be made successfully. First, the real potential and usefulness of multicomponent data for mineral exploration needs to be demonstrated. Only a limited number of surveys have been acquired with this technology. Results are promising, but the best processing and imaging strategies still are ahead of us. Second, a significant effort should be made to produce high-quality true-amplitude sections or volumes. This is a significant challenge because many mining areas generally are characterized with low signal-to-noise ratio and discontinuous reflections that are difficult to image without the application of prestack automatic gain control to equalize amplitudes. Up to now, most case studies reported in the literature are not processed following AVO-friendly or true-amplitude processing flows. Finally, more information on the physical rock properties of complete ore systems is required to assess realistic seismic signatures. Work conducted in this area so far provides good indications on the average properties of an orebody. However, this is not sufficient, especially when knowing that ore systems are complex and are composed of several different components that are not distributed uniformly. Detailed petrophysical data combined with modeling tools should help improve our understanding of wavefields produced from complex, but realistic ore systems. This aspect is even more important for detailed seismic work conducted at the mine scale.

Diffractions, as illustrated by Khaidokov et al. (2004), were long treated as insignificant to traditional seismic processing and imaging. However, they contain useful information about the media velocity, anisotropy, target composition, and resolution. Therefore, although advanced processing algorithms (such as depth imaging methods) seem appropriate in imaging the complex geology of mining areas, the traditional DMO-stack (for diffraction identification) and poststack migration (to properly locate diffractors) method may be the only practical method because it allows the preservation of diffractions. Therefore, this algorithm is recommended to be implemented in the early processing stages to allow any potential diffraction to be preserved prior to migration (see also Eaton et al., 2003). For structural imaging, prestack depth migration algorithms should be best suited; however, prestack depth imaging is more sensitive to velocity model errors and statics, although DMO-based imaging algorithms appear to be relatively robust. Obtaining an accurate velocity model in hard-rock environments is challenging; nevertheless, therein lies an opportunity for specific method developments in depth imaging tailored for mining applications.

Although 3D surveys are not yet the norm in hard-rock exploration, 2D surveys confined to existing roads and forest tracks are very common. Therefore, it is important to make it clear to mining companies that drilling based on 2D seismic surveys is highly risky because it is common to image out-of-the-plane structures in 2D seismic data, especially in the complex folded, deformed, and faulted geology of mining areas (e.g., Malehmir et al., 2010). Detailed deep exploration drilling programs only should be considered after the implementation of 3D surveys. Three-dimensional seismic surveys also should be acquired with the main aim of providing information at a resolution comparable with $2 \mathrm{D}$ profiles. The fact that several 3D surveys exhibit lower quality seismic images than 2D images (see Vestrum and Gittins, 2009; Cheraghi et al., 2012) raises a point of concern about data density. High-fold 3D data should be acquired with a careful seismic data acquisition design.
Geologic conditions encountered in hard-rock environments differ significantly from sedimentary environments. Consequently, the transfer of knowledge from the oil and coal industries to the mineral industry is not always straightforward. For example, although acoustic inversion in soft rocks is a standard procedure, it is still poorly understood and underused in hard rocks. Harrison and Urosevic (2012) carry out 2D acoustic inversion and suggest that changes in acoustic impedance are possibly the most important seismic attribute, but these changes are not unique for different rock types. Hence, additional seismic attributes should be used to help characterize the rock type and rock alteration. Their results suggest that inversion (acoustic and elastic) of high-resolution 3D data may play a very important role in hard-rock seismic exploration in the future.

Petrophysical studies, specific acquisition approaches (target illumination), processing techniques (time and depth wavefield extrapolation and image reconstruction) and volumetric seismic interpretation that incorporates various seismic attributes, inversion, image processing routines, modeling and a high-level calibration of seismic data are needed. Although the hydrocarbon and mining environments differ, hard-rock seismic methodologies may be expected to continue to take advantage of advances in the seismic acquisition technology that is being driven by the hydrocarbon industry. In particular, the use of wireless recording systems and multicomponent sensors may be expected to expand in the future. To reduce the costs of $3 \mathrm{D}$ surveys, research on and development of hard-rock specific seismic sources is necessary. The lower attenuation (higher $Q$, due to the fact that scattering attenuation is more important because absorption is less prevalent) in hard rocks implies that sources that are suitable for the soft rock environment and developed by the hydrocarbon industry for probing it may not be the optimum for the hard-rock environment. Therefore, research on the development of high-frequency, low-cost seismic sources for mining applications is deemed necessary.

Three-dimensional integration of seismic results with verified geologic observations and other geophysical results will become an important interdisciplinary approach in most major mining camps worldwide. Three-dimensional, and even 4D geologic modeling studies (e.g., Dehghannejad et al., 2012), based on regional and mining camp scales and, sometimes, mine scale information, will be very important in limiting exploration targets suitable for 3D surveys and/or downhole seismic studies. A complete and comprehensive data integration program combined with modeling will help to reduce speculative interpretation, especially at greater depths, and provide greater value to industry.

\section{CONCLUSIONS}

We have presented past and recent trends in the use of seismic methods in mineral exploration and mine planning. It is obvious that seismic methods are becoming an important exploration tool, especially for depths greater than $500 \mathrm{~m}$, where common geophysical methods lack the necessary resolution. In addition, 3D seismic surveys are becoming essential for mine planning. A complementary product of these 3D surveys is that new resources can be identified in conjunction with them. In order for seismic methodology to become even more common in the mining environment the cost of the surveys need to be further reduced. This will require that advances in seismic acquisition methodology within the hydrocarbon industry are adapted to the hard-rock environment. However, research 
and development on hard-rock specific sources also is required. Higher $Q$ and generally lower reflection coefficients in the hardrock environment imply that seismic sources developed for the hydrocarbon industry may not be optimal. Once costs for seismic surveys reach a level where there is an obvious return in performing the survey, then more and more cases of direct detection of mineral deposits will arise. We expect the recent trend of increased use of seismic methods in the mining industry to accelerate in the coming years.

\section{ACKNOWLEDGMENTS}

We are thankful to Calin Cosma, Mahdieh Dehghannejad, Nicoleta Enescu, Matthew Salisbury, Ilmo Kukkonen, Mark Gibson, Charles Pretorius, Lindsay Linzer, and Jeanne Trickett for providing materials for this publication. We thank Dannemora Mineral AB, Boliden Mineral AB, the Geological Survey of Sweden, Xstrata, and Anglo Gold for their kind permission to use their materials in this paper. A. Malehmir and R. Durrheim acknowledge funding provided by the Swedish International Development Cooperation Agency (SIDA) and Meeting Points Mining to review research in the mineral exploration industry in Sweden and South Africa. We also thank Consolidated Mineral and Gold Fields for allowing us to show seismic images. Landmark Graphics (Halliburton) is thanked for providing the software. We acknowledge constructive comments provided by $\mathrm{C}$. Hurich and four anonymous reviewers along with associate editor Colin Farquharson and assistant editor Ivan Vasconcelos, which helped to improve the quality of our paper.

\section{REFERENCES}

Adam, E., B. Milkereit, G. Arnold, and R. Pineault, 1996, Seismic response of the Bell Allard orebody, Matagami, Quebec: 66th Annual International Meeting, SEG, Expanded Abstracts, 634-637.

Adam, E., B. Milkereit, and M. Mareschal, 1998, Seismic reflection and borehole geophysical investigations in the Matagami mining camp: Canadian Journal of Earth Sciences, 35, 686-695, doi: 10.1139/e98-022.

Adam, E., B. Milkereit, M. Mareschal, A. E. Barnes, C. Hubert, and M. Salisbury, 1992, The application of reflection seismology to the investigation of the geometry of near-surface units and faults in the Blake River Group, Abitibi Belt, Quebec: Canadian Journal of Earth Sciences, 29, 2038-2045, doi: 10.1139/e92-160.

Adam, E., G. Perron, G. Arnold, L. Matthews, and B. Milkeriet, 2003, 3D seismic imaging for VMS deposit exploration, Matagami, Quebec, in D. W. Eaton, B. Milkereit, and M. H. Salisbury, eds., Hard rock seismic exploration: SEG.

Adam, E., G. Perron, B. Milkereit, J. Wu, A. J. Calvert, M. Salisbury, P. Verpaelst, and D. J. Dion, 2000, A review of high-resolution seismic profiling across the Sudbury, Selbaie, Noranda, and Matagami mining camps: Canadian Journal of Earth Sciences, 37, 503-516, doi: 10.1139/e99-064.

Adam, E., W. Qian, and B. Milkereit, 2007, In the shadow of a headframe: Deep exploration using integrated 3-D seismic and BHEM at the Louvicourt mine, Québec, in B. Milkereit, ed., Proceedings of Exploration 07: Fifth Decennial International Conference on Mineral Exploration, 1049-1053.

Ayarza, P., C. Juhlin, D. Brown, M. Beckholmen, G. Kimbell, R. Pechning, L. Pevzner, R. Pevzner, C. Ayala, M. Bliznetsov, A. Glushkov, and A. Rybalka, 2000, Integrated geological and geophysical studies in the SG4 borehole area, Tagil Volcanic Arc, Middle Urals: Location of seismic reflectors and source of the reflectivity: Journal of Geophysical Research, 105, 21333-21352, doi: 10.1029/2000JB900137.

Bate, S., 2011, Geophysics as a tool to assist in understanding a region's underlying lithologic and structural regime, delineating economic mineral resources, and assisting in geotechnical and engineering studies: Examples from Botswana and South Africa: Proceedings Geosynthesis.

Bauer, T., P. Skyttä, R. L. Allen, and P. Weihed, 2011, Syn-extensional faulting controlling structural inversion - Insights from the Palaeoproterozoic Vargfors syncline, Skellefte mining district, Sweden: Precambrian Research, 191, 166-183, doi: 10.1016/j.precamres.2011.09.014.

Bellefleur, G., A. Malehmir, and C. Müller, 2012, Elastic finite-difference modeling of volcanic-hosted massive sulfide deposits: A case study from Halfmile Lake, New Brunswick, Canada: Geophysics, 77, this issue.
Bellefleur, G., L. Matthews, B. Roberts, B. McMonnies, M. Salisbury, G. Perron, D. Snyder, and J. McGaughey, 2004a, Downhole seismic imaging of the Victor kimberlite, James Bay Lowlands, Canada: A feasibility study: 74th Annual International Meeting, SEG, Expanded Abstracts, 1229-1232.

Bellefleur, G., C. Müller, D. Snyder, and L. Matthews, 2004b, Downhole seismic imaging of a massive sulphide orebody with mode-converted waves, Halfmile Lake, New Brunswick, Canada: Geophysics, 69, 318329, doi: 10.1190/1.1707051.

Berson, I. S., 1957, High-frequency seismic: Moscow, USSR Academy of Science, 239 (in Russian).

Bohlen, T., C. Müller, and B. Milkereit, 2003, Elastic wave scattering from massive sulfide orebodies: On the role of composition and shape, in B. Milkereit, D. Eaton, and M. Salisbury, eds., Hard rock seismic exploration: SEG, 70-89.

Calvert, A. J., and Y. Li, 1999, Seismic reflection imaging over a massive sulfide deposit at the Matagami mining camp, Quebec: Geophysics, 64, 24-32, doi: 10.1190/1.1444521.

Calvert, A. J., G. Perron, and Y. Li, 2003, A comparison of 2D seismic lines shot over the Ansil and Bell Allard mines in the Abitini Greenstone belt, in D. Eaton, B. Milkereit, and M. Salisbury, eds., Hardrock seismic exploration: SEG, 164-177.

Campbell, G., 1990, The seismic revolution in gold and platinum prospecting: South African Geophysical Association Yearbook, 37-45.

Campbell, G., 1994, Geophysical contributions to mine-development planning: A risk reduction approach, in C. R. Anhaeusser, ed., Proceedings XV CMMI Congress: SAIMM Symposium Series, 283-325.

Campbell, G., 2011, Exploration geophysics of the Bushveld Complex in South Africa: The Leading Edge, 30, no. 6, 622-637, doi: 10.1190/1 .3599148 .

Campbell, G., and J. H. Crotty, 1988, The application of 3-D seismic surveys to mine planning: South African Chamber of Mines MINTEK Seminar, 4th March.

Campbell, G., and J. H. Crotty, 1990, 3-D seismic mapping for mine planning purposes at the South Deep Prospect, in D. A. J. Ross-Watt, and P. D. K. Robinson, eds., Proceedings International Deep Mining Conference: SAIMM Symposium Series S1O, 2, 569-597.

Campbell, G., and D. G. Peace, 1984, Seismic reflection experiments for gold exploration, Wits Basin, Republic of South Africa: 46th Annual International Conference and Exhibition, EAGE, Extended Abstracts.

Cao, S., and S. A. Greenhalgh, 1995, High resolution seismic tomographic delineation of ore deposits: Exploration Geophysics, 26, 315-318, doi: 10 1071/EG995315.

Cao, S., and S. A. Greenhalgh, 1997, Crosswell seismic tomographic delineation of mineralization in a hard rock environment: Geophysical Prospecting, 45, 449-460, doi: 10.1046/j.1365-2478.1997.370280.x.

Chambovet, G., 2006, Seismic method applied to platinum exploration, a success story: Keynote address to 2006 International Platinum Conference, South African Institute of Mining and Metallurgy.

Chen, G., G. Liang, D. Xu, Q. Zeng, S. Fu, X. Wei, Z. He, and G. Fu, 2004 Application of a shallow seismic reflection method to the exploration of a gold deposit: Journal of Geophysics and Engineering, 1, 12-16, doi: 10 .1088/1742-2132/1/1/002.

Cheraghi, S., A. Malehmir, and G. Bellefleur, 2011, 2-D seismic reflection imaging in the Brunswick no. 6 massive sulphide and iron deposits, Bathurst Mining Camp, Canada: Implications for crustal architecture and mineral potential: Tectonophysics, 506, 55-72, doi: 10.1016/j.tecto.2011.04.011.

Cheraghi, S., A. Malehmir, and G. Bellefleur, 2012, 3D imaging challenges in steeply dipping mining environment: New lights on acquisition geometry and processing from the Brunswick no. 6 seismic data, Canada: Geophysics, 77, this issue.

Clowes, R. M., A. G. Green, C. J. Yorath, E. R. Kanasewich, G. F. West, and G. D. Garland, 1984, LITHOPROBE - a national program for studying the third dimension of geology: Journal of the Canadian Society of Exploration Geophysicists, 20, 23-39.

Cosma, C., 1983, Determination of rock mass quality by a crosshole seismic method: Bulletin - International Association for Engineering Geology, 26/27, 209-225.

Cosma, C., and N. Enescu, 2003, Ore delineation by crosshole seismics, transmission and reflection imaging at Voisey's Bay, Canada: Proceedings of the Seventh International Symposium on Recent Advances in Exploration Geophysics.

Cosma, C., and N. Enescu, 2011, Seismic side-scan for wide-range highresolution imaging around boreholes: EAGE Borehole Geophysics Workshop, BG22.

Cosma, C., P. Heikkinen, and J. Keskinen, 2003, Multiazimuth VSP for rock characterisation of deep nuclear waste disposal sites in Finland, in D. Eaton, B. Milkereit, and M. Salisbury, eds, Hardrock seismic exploration, 10: SEG, 207-226.

Cosma, C., P. Heikkinen, J. Keskinnen, and N. Enescu, 2001, VSP in crystalline rocks-from downhole velocity profiling to 3D fracture mapping: International Journal of Rock Mechanics and Mining Sciences and 
Geomechanics Abstracts, 38, 843-850, doi: 10.1016/S1365-1609(01) 00049-1.

Cosma, C., A. Wolmarans, D. Eichenburg, and N. Enescu, 2007, Kimberlite delineation by seismic side-scans from boreholes: Exploration in the New Millennium, Proceedings of the Fifth Decennial International Conference on Mineral Exploration.

Dahle, A., H. Gjoystdal, G. Grammeltvedt, and T. Soyland Hansen, 1985, Applications of seismic reflection methods for ore prospecting in crystalline rock: First Break, 3, 9-16.

Davison, G. E., and G. K. Chunnett, 1999, Seismic exploration for Merensky Reef: The way ahead: South African Journal of Geology, 102, 261-267.

Dehghannejad, M., T. Bauer, A. Malehmir, C. Juhlin, and P. Weihed, 2012a, Crustal geometry of the central Skellefte district, northern Swedenconstraints from reflection seismic investigations: Tectonophysics, 524-525, 87-99 doi: 10.1016/j.tecto.2011.12.021.

Dehghannejad, M., C. Juhlin, A. Malehmir, P. Skyttä, and P. Weihed, 2010, Reflection seismic imaging of the upper crust in the Kristineberg mining area, northern Sweden: Journal of Applied Geophysics, 71, 125-136. doi: 10.1016/j.jappgeo.2010.06.002.

Dehghannejad, M., A. Malehmir, C. Juhlin, and P. Skyttä, 2012, 3D constraints and finite-difference modeling of massive sulfide deposits: The Kristineberg seismic lines revisited, northern Sweden: Geophysics, 77, this issue.

De Wet, J. A. J., and D. A. Hall, 1994, Interpretation of the Oryx 3-D seismic survey, in C. R. Anhaeusser, ed., Proceedings XV CMMI Congress: SAIMM Symposium Series, S14, 3, 259-270.

Dortman, N. B., and M. S. Magid, 1969, Relations of a velocity of elastic waves and a density of rocks with crystal-chemical characteristics of minerals: Geology and Geophysics, 77, 93-105 (in Russian).

Duff, D., C. Hurich, and S. Deemer, 2012, Seismic properties of the Voisey's Bay massive sulfide deposit: Insights into approaches to seismic imaging: Geophysics, 77, this issue.

Duncan, G., M. Downey, L. Leung, and P. Harman, 1989, The development of crosshole seismic techniques and case studies: Exploration Geophysics, 20, 127-130, doi: 10.1071/EG989127.

Durrheim, R. J., 1986, Recent reflection seismic developments in the Witwatersrand Basin, in M. Barazangi, and L. Brown, eds., Reflection seismology: A global perspective: AGU, 13, 77-83, of Geodynamics Series.

Durrheim, R. J., 2007, The DeepMine and FutureMine research programmes - Knowledge and technology for deep gold mining in South Africa, in $\mathrm{Y}$ Potvin, J. Hadjigeorgiou, and D. Stacey, eds., Challenges in deep and high stress mining: Australian Centre for Geomechanics, 131-141.

Durrheim, R. J., and M. J. Maccelari, 1991, Seismic exploration for precious metals in the hard rock environment: 61st Annual International Meeting, SEG, Expanded Abstracts, 159-162.

Durrheim, R. J., L. O. Nicolaysen, and B. Corner, 1991, A deep seismic reflection profile across the Archean-Proterozoic Witwatersrand Basin, South Africa, in R. Meissner, L. Brown, H.-J. Dürbaum, W. Franke, K. Fuchs, and F. Seifert, eds., Continental lithosphere: Deep seismic reflections: AGU, 22, 213-224.

Duweke, W., J. C. Trickett, K. Tootal, and M. Slabbert, 2002, Threedimensional reflection seismics as a tool to optimise mine design, planning and development in the Bushveld Igneous Complex: 64th Annual International Conference and Exhibition, EAGE, Extended Abstracts.

Eaton, D. W., 1999, Weak elastic-wave scattering from massive sulfide ore bodies: Geophysics, 64, 289-299, doi: 10.1190/1.1444525.

Eaton, D. W., E. Adam, B. Milkereit, M. Salisbury, B. Roberts, D. White, and J. Wright, 2010, Enhancing base-metal exploration with seismic imaging: Canadian Journal of Earth Sciences, 47, 741-760, doi: 10.1139/ E09-047.

Eaton, D. W., S. Guest, B. Milkereit, W. Bleeker, D. Crick, D. Schmitt, and M. Salisbury, 1996, Seismic imaging of massive sulfide deposits: Part III, Borehole seismic imaging of near-vertical structures: Economic Geology, 91, 835-840, doi: 10.2113/gsecongeo.91.5.835.

Eaton, D., B. Milkereit, and M. Salisbury, 2003, Hardrock seismic exploration: Mature technologies adapted to new exploration targets, Foreword to hardrock seismic exploration: SEG, 1-6.

Ehsan, S. A., A. Malehmir, and M. Dehghannejad, 2012, Reprocessing and interpretation of $2 \mathrm{D}$ seismic data from the Kristineberg mining area, northern Sweden: Journal of Applied Geophysics, 80, 43-55, doi: 10 .1016/j.jappgeo.2012.01.004.

Elliot, C. L., 1967, Some applications of refraction techniques in mining exploration, in A. Musgrave, ed., Seismic refraction prospecting: SEG, 522-538.

Evans, B. J., M. Urosevic, and A. Taube, 2003, Using surface-seismic reflection to profile a massive sulfide deposit at Mount Morgan, Australia, in D. Eaton, B. Milkereit, and M. Salisbury, eds, Hardrock seismic exploration: SEG, Geophysical Development, 10, 157-163.

Fatti, J., 1987, Reflection seismic surveys in the Karoo Basin by Soekor: South African Geophysical Association Yearbook, 22-30.
Frappa, M., and C. Moinier, 1993, Shallow seismic reflection in a mine gallery: Engineering Geology, 33, 201-208, doi: 10.1016/0013-7952(93) 90058-K.

Friedel, M. J., M. J. Jackson, D. F. Scott, T. J. Williams, and M. S. Olson, 1995, 3-D tomographic imaging of anomalous conditions in a deep silver mine: Journal of Applied Geophysics, 34, 1-21, doi: 10.1016/0926-9851 (95)00007-O.

Friedel, M. J., D. F. Scott, M. J. Jackson, T. J. Williams, and S. M. Killen, 1996, 3-D tomographic imaging of anomalous stress conditions in a deep US gold mine: Journal of Applied Geophysics, 36, 1-17, doi: 10.1016/ S0926-9851(96)00027-4.

Galperin, E. I., 1985, Vertical seismic profiling and its exploration potential: D. Reidel Publishing Co.

Gamburtsev, G. A., Y. V. Riznichenko, I. S. Berson, A. M. Epinatieva, Y. V. Karus, and I. P. Kosminskaya, 1952, Correlation method of refraction waves: USSR Academy of Science, 239 (in Russian).

Gendzwill, D., 1990, High-resolution seismic reflections in an underground mine: 60th Annual International Meeting, SEG, Expanded Abstracts, 397-398.

Gendzwill, D. J., and S. D. Matieshin, 1996, Seismic reflection survey of a kimberlite intrusion in the Fort á la Corne district, Saskatchewan, in A. N. LeCheminant, D. G. Richardson, R. N. W. Dilabio, and K. A. Richardson, eds., Searching for diamonds in Canada: Geological Survey of Canada Open File Report 3228, 251-253.

Gibson, M. A. S., S. J. Jolley, and A. C. Barnicoat, 2000, Interpretation of the Western ultra deep levels 3D seismic survey: The Leading Edge, 19, 730-735, doi: 10.1190/1.1438704.

Gillot, E., M. Gibson, D. Verneau, and S. Laroche, 2005, Application of high-resolution 3D seismic to mine planning in shallow platinum mines: First Break, 59-64.

Gladwin, M., 1982, Ultrasonic stress monitoring in underground mining: International Journal of Rock Mechanics and Mining Sciences and Geomechanics Abstracts, 19, 221-228, doi: 10.1016/0148-9062(82)90220-0.

Goleby, B., R. Korsch, T. Fomin, B. Bell, M. G. Nicoll, B. J. Drummond, and A. J. Owen, 2002, Preliminary 3-D geological model of the Kalgoorlie region, Yilgarn Craton, Western Australia, based on deep seismicreflection and potential-field data: Australian Journal of Earth Sciences, 49, 917-933.

Gray, N. K., R. E. Tucker, and D. J. Kershaw, 1994, The sun project-I Discovery of a major new Witwatersrand goldfield, in C. R. Anhaeusser, ed., Proceedings XV CMMI Congress: SAIMM Symposium Series S14, 3, 95-102.

Green, A. G., and J. A. Mair, 1983, Subhorizontal fractures in a granitic pluton: Their detection and implications for radioactive waste disposal: Geophysics, 48, 1428-1449, doi: 10.1190/1.1441428.

Greenhalgh, S. A., and S. Bierbaum, 1998, A donwhole sparker sound source for crosswell seismic surveying: Exploration Geophysics, 29, 280-283, doi: 10.1071/EG998391.

Greenhalgh, S. A., and I. M. Mason, 1997, Seismic imaging with application to mine layout and development, in A. C. Gubins, ed., Exploration97: Geophysics and geochemistry at the Millenium: GEO/FX Publishers, 585-598.

Greenhalgh, S. A., I. M. Mason, and C. Sinadinovski, 2000, In-mine seismic delineation of mineralization and hard rock structure: Geophysics, $\mathbf{6 5}$ 1908-1919, doi: 10.1190/1.1444875.

Greenhalgh, S. A., B. Zhou, and S. Cao, 2003, A crosswell seismic experiment for nickel sulphide mineralization: Journal of Applied Geophysics, 53, 77-89, doi: 10.1016/S0926-9851(03)00029-6.

Greenwood, A., 2012, Hydrophone VSP surveys in hard rock: Geophysics, 77, this issue.

Greenwood, A., C. Dupuis, A. Hashemi, and M. Urosevic, 2010, Hydrophone VSP imaging in the Agnew-Wiluna Belt, Western Australia 21st International Geophysical Conference and Exhibition, ASEG, Preview 147

Gupta, R. R., 1971, Seismic determination of geological discontinuities ahead of rapid excavation: Semi Annual Report No. 6051: Bendix Research Laboratory, 40

Gustavsson, M., P. Moren, R. Pihl, and S. Ivansson, 1984, An experiment with the seismic cross-hole method in an iron mine: The Leading Edge, 3, 143-145, doi: 10.1190/1.1439029.

Gyorfi, I., Z. Hajnal, D. J. White, E. Takacs, B. Reilkoff, I. R. Annesley, B Powell, and R. Koch, 2007, High-resolution seismic survey from the McArthur River region: Contributions to mapping of the complex P2 uranium ore zone, Athabasca Basin, Saskatchewan, in C. W. Jefferson, and G. Delaney, eds., EXTECH IV: Geology and uranium exploration technology of the Proterozoic Athabasca Basin, Saskatchewan and Alberta: Geological Survey of Canada, Bulletin 588 (also Saskatchewan Geological Society, Special Publication 17: Geological Association of Canada, Mineral Deposits Division, Special Publication, 4, 389-412.

Hajnal, Z., I. R. Annesley, D. White, R. B. Matthews, V. Sopuck, R. Koch, M. Leppin, and S. Ahuja, 1997, Sedimentary-hosted mineral deposits: A 
high resolution seismic survey in the Athabasca Basin, in A. G. Gubins, ed., Geophysics and geochemistry at the millenium: Proceedings of Exploration 97: Fourth Decennial Conference on Mineral exploration, GEO/ FX, 421-432.

Hajnal, Z., D. White, E. Takacs, S. Gyorfi, I. R. Annesley, G. Wood, C. O'Dowd, and G. Nimeck, 2010, Application of modern 2D and 3D seismic reflection techniques for uranium exploration in the Athabasca Basin, in Lithoprobe: Parameters, processes and the evolution of a continent: Canadian Journal of Earth Sciences special issue, 47, 761-782, doi: 10.1139/E10-026.

Hammer, P. T. C., R. M. Clowes, and K. Ramachandran, 2004, Highresolution seismic reflection imaging of a thin, diamondiferous kimberlite dyke: Geophysics, 69, 1143-1154, doi: 10.1190/1.1801932.

Harman, P., L. Leung, and M. Downey, 1987, Crosshole seismic survey for mineral exploration in the West Kimberley Area, Western Australia: Exploration Geophysics, 18, 80-83, doi: 10.1071/EG987080.

Harrison, C., and M. Urosevic, 2012, Targeting gold deposits from seismic data - Case study form Western Australia: Geophysics, 77, this issue.

Haslett, M. J., 1994, The South Deep Project: Geology and planning for the future, in C. R. Anhaeusser, ed., Proceedings XV CMMI Congress: SAIMM Symposium Series S14, 3, 71-83.

Hawkins, L., and R. J. Whiteley, 1980, The seismic signature of the Elura orebody: ASEG Bulletin, 11, 375-329.

Hübert, J., A. Malehmir, M. Smirnow, A. Tryggvason, and L. B. Pedersen, 2009, MT measurements in the western part of the Paleoproterozoic Skellefte Ore District, northern Sweden: A contribution to an integrated geophysical study: Tectonophysics, 475, 493-502, doi: 10.1016/j.tecto.2009 .06 .011 .

Ji, S., Q. Wang, and B. Xia, 2002, Handbook of seismic properties of minerals, rocks and ores: Polytechnique International Press, 630

Juhlin, C., 1995, Imaging of fracture zones in the Finnsjön area, central Sweden, using the seismic reflection method: Geophysics, 60, 66-75, doi: 10.1190/1.1443764.

Juhlin, C., S. Å. Elming, C. Mellqvist, B. Öhlander, P. Weihed, and A. Wikström, 2002, Crutsal reflectivity near the Archaean-Proterozoic boundary in northern Sweden and implications for the tectonic evolution of the area: Geophysical Journal International, 150, 180-197, doi: 10 $.1046 /$ j.1365-246X.2002.01706.x.

Juhlin, C., S. Kashubin, J. Knapp, V. Makovsky, and T. Ryberg, 1995 EUROPROBE seismic reflection profiling in the Urals: The ESRU project: EOS, 76, 193-198.

Juhlin, C., J. Lindgren, and B. Collini, 1991, Interpretation of seismic reflection and borehole data from Precambrian rocks in the Dala Sandstone area, central Sweden: First Break, 9, 24-36.

Juhlin, C., and H. Palm, 1999, 3-D structure below Avrö island from highresolution reflection seismic studies, southeastern Sweden: Geophysics, 64, 662-667, doi: 10.1190/1.1444575.

Juhlin, C., and M. Stephens, 2006, Gently dipping fracture zones in Paleoproterozoic metagranite, Sweden: Evidence from reflection seismic and cored borehole data, and implications for the disposal of nuclear waste: Journal of Geophysical Research, 111, B09302, doi: 10.1029/ 2005JB003887.

Juhojuntti, N., G. Wood, C. Juhlin, C. O'Dowd, P. Dueck, and C. Cosma, 2012, 3D seismic survey at the Millennium uranium deposit, Saskatchewan, Canada: Mapping depth to basement and imaging post-Athabasca structure near the ore body: Geophysics, 77 , this issue.

Karaev, N. A., and G. Y. Rabinovich, 1995, Atlas of seismic models and wave fields of ore regions, VIRG (in Russian).

Karaev, N. A., and G. Y. Rabinovich, 2000, Ore seismic: Moscow, Geoinformmark, 366 (in Russian).

Kehrman, R. F., 1980, Development of a shallow penetration acoustic reflection technique for mining geology: Final Report Contract No. HO262007: Westinghouse Electric Corporation, 178.

Khaidukov, V., E. Landa, and T. Moser, 2004, Diffraction imaging by focusing-defocusing: An outlook on seismic superresolution: Geophysics, 69, 1478-1490, doi: 10.1190/1.1836821.

Koivisto, E., A. Malehmir, P. Heikkinen, S. Heinonen, and I. Kukkonen, 2012, 2D reflection seismic investigations in the Kevitsa Ni-Cu-PGE deposit, northern Finland: Geophysics, 77, this issue.

Korja, A., and P. Heikkinen, 2005, The accretionary Svecofennian orogeninsight from the BABEL profiles: Precambrian Research, 136, 241-268, doi: 10.1016/j.precamres.2004.10.007.

Krylov, S. V., A. V. Brykin, and E. N. Ten, 1990, Elastic properties of silicate minerals and crystalline rocks for the isotropic model: Geology and Geophysics, 12, 101-113 (in Russian).

Kukkonen, I., S. Heinonen, P. Heikkinen, and P. Sorjonen-Ward, 2012 Delineating ophiolite-derived host rocks of massive sulfide $\mathrm{Cu}-\mathrm{Co}-\mathrm{Zn}$ deposits with 2D high-resolution seismic reflection data in Outokumpu, Finland: Geophysics, 77, this issue.

Kukkonen, I. T., ed., 2011a, Outokumpu deep drilling project 2003-2010 special paper 51: Geological Survey of Finland, http://arkisto.gtk.fi/sp/ sp51/sp51.pdf, accessed December 2011
Kukkonen, I. T., P. Heikkinen, S. Heinonen, and J. Laitinen, and HIRE Working Group, 2011b, Reflection seismics in exploration for mineral deposits: Initial results from the HIRE project: Geoscience for society: 125th anniversary volume: Geological Survey of Finland, 49-58.

Kukkonen, I. T., and R. Lahtinen, eds., 2006, Finnish reflection experiment FIRE 2001-2005: Geological Survey of Finland, Special Paper 43, 247 , ISBN: 951-690-963-9.

Larroque, M., J.-P. Postel, M. Slabbert, and W. Duweke, 2002, How 3D seismic can help enhance mining?: First Break, 20, 472-475.

Mair, J. A., and A. G. Green, 1981, High-resolution seismic reflection profiles reveal fracture zones within a "homogeneous" granite batholith: Nature, 294, 439-442, doi: 10.1038/294439a0.

Malehmir, A., M. Andersson, M. Lebedev, M. Urosevic, and V. Mikhaltsevitch, 2012a, Experimental estimation of velocities and anisotropy of a series of Swedish crystalline rocks and ores: Geophysical Prospecting, doi: 10.1111/j.1365-2478.2012.01063.x.

Malehmir, A., and G. Bellefleur, 2009, 3D seismic reflection imaging of VHMS deposits, Insights from reprocessing of the Halfmile Lake data, New Brunswick, Canada: Geophysics, 74, no. 6, B209-B219, doi: 10 $.1190 / 1.3230495$.

Malehmir, A., and G. Bellefleur, 2010, Reflection seismic imaging and physical properties of base-metal and associated iron deposits in the Bathurst Mining Camp, New Brunswick, Canada: Ore Geology Reviews, 38, 319333. doi: 10.1016/j.oregeorev.2010.08.002.

Malehmir, A., G. Bellefleur, and C. Müller, 2010, 3D diffraction and modeconverted scattering signatures of base-metal deposits, Bathurst Mining Camp, Canada: First Break, 28, 41-45.

Malehmir, A., P. Dahlin, E. Lundberg, C. Juhlin, H. Sjöström, and K. Högdahl, 2011, Reflection seismic investigations in the Dannemora area, central Sweden: Insights into the geometry of poly-phase deformation zones and magnetite-skarn deposits: Journal of Geophysical Research, 116, B11307. doi: 10.1029/2011JB008643.

Malehmir, A., C. Juhlin, C. Wijns, M. Urosevic, P. Valasti, and E. Koivisto 2012b, 3D reflection seismic investigation for open-pit mine planning and exploration in the Kevitsa Ni-Cu-PGE deposit, northern Finland: Geophysics, 77, this issue.

Malehmir, A., C. Schmelzbach, E. Bongajum, G. Bellefleur, C. Juhlin, and A. Tryggvason, $2009 \mathrm{a}, 3 \mathrm{D}$ constraints on a possible deep $>2.5 \mathrm{~km}$ massive sulphide mineralization from $2 \mathrm{D}$ crooked-line seismic reflection data in the Kristineberg mining area, northern Sweden: Tectonophysics, 479, 223-240, doi: 10.1016/j.tecto.2009.08.013.

Malehmir, A., H. Thunehed, and A. Tryggvason, 2009b, The Paleoproterozoic Kristineberg mining area, northern Sweden: Results from integrated 3D geophysical and geologic modeling, and implications for targeting ore deposits: Geophysics, 74, no. 1, B9-B22, doi: 10.1190/1.3008053.

Malehmir, A., A. Tryggvason, C. Juhlin, J. Rodriguez-Tablante, and P. Weihed, 2006, Seismic imaging and potential field modeling to delineate structures hosting VHMS deposits in the Skellefte Ore District, northern Sweden: Tectonophyiscs, 426, 319-334, doi: 10.1016/j.tecto.2006.08 006 .

Malehmir, A., A. Tryggvason, H. Lickorish, and P. Weihed, 2007, Regional structural profiles in the western part of the Palaeoproterozoic Skellefte Ore District, northern Sweden: Precambrian Research, 159, 1-18, doi: 10 .1016/j.precamres.2007.04.011

Malinowski, M., E. Schetselaar, and D. White, 3D seismic imaging in the Flin Flon VMS mining camp - Part II: Forward modeling: Geophysics, 77, this volume.

Malinowski, M., and D. White, 2011, Converted wave seismic imaging in the Flin Flon mining camp: Journal of Applied Geophysics, 75, 719-730, doi: 10.1016/j.jappgeo.2011.09.026.

Mathibele, K., 2007, 2-D reflection seismological investigations of the geological structures beneath Jwaneng Mine Area: B.S. dissertation, University of the Witwatersrand, 37.

Mathur, S. P., F. J. Moss, and J. C. Branson, 1977, Seismic and gravity investigations along the Geotraverse, Western Australia, 1969, Bureau of Mineral Resources, Geology and Geophysics, Bulletin 191.

Matthews, L., 2002, Base metal exploration: Looking deeper and adding value with seismic data: CSEG Recorder, 27, 37-43.

Maxwell, S. C., and R. P. Young, 1992, Sequential velocity imaging and microseismic monitoring of mining induced stress change: Pure and Applied Geophysics, 139, 421-447, doi: 10.1007/BF00879945.

Milkereit, B., E. Adam, A. Barnes, C. Beaudry, R. Pineault, and A. CinqMars, 1992a, An application of reflection seismology to mineral exploration in the Matagami area, Abitibi Belt, Quebec: Current Research, Part C, $13-18$.

Milkereit, B., E. K. Berrer, A. R. King, A. H. Watts, B. Roberts, E. Adam, D. W. Eaton, J. Wu, and M. H. Salisbury, 2000, Development of 3-D seismic exploration technology for deep nickel-copper deposits - A case history from the Sudbury basin, Canada: Geophysics, 65, 1890-1899, doi: 10 $.1190 / 1.1444873$.

Milkereit, B., and D. Eaton, 1998, Imaging and interpreting the shallow crust: Tectonophysics, 286, 5-18, doi: 10.1016/S0040-1951(97)00251-5. 
Milkereit, B., D. W. Eaton, J. Wu, G. Perron, M. H. Salisbury, E. Berrer, and G. Morrison, 1996, Seismic imaging of massive sulphide deposits: Part II. Reflection seismic profiling: Economic Geology, 91, 829-834, doi: 10 2113/gsecongeo.91.5.829.

Milkereit, B., and A. Green, and the Sudbury Working Group, 1992c, Deep geometry of the Sudbury structure from seismic reflection profiling: Geology, 20, 807-811.

Milkereit, B., L. Reed, and A. Cinq-Mars, 1992b, High frequency reflection seismic profiling at Les Mines Selbaie, Quebec: Current Research, Part E, $217-224$.

Moss, F. J., and P. Jones, 1974, Ngalia Basin seismic survey, Northern Territory: Bureau of Mineral Resources, Geology and Geophysics, Record $1974 / 49$.

Mueller, C., G. Bellefleur, E. Adam, G. Perron, M. Mah, and D. Snyder, 2012, Performance of low-fold scalar migration for downhole seismic imaging of massive sulphide ore deposits at Norman West, Sudbury, Canada: Geophysics, 77, this issue.

Mutyorata, J. J., 1987, High resolution seismic reflection: An exploration tool, in an underground experiment, an example from Zimbabwe: Journal of African Earth Sciences, 6, 109-115.

Nedimović, M. R., and G. F. West, 2003, Crooked-line 2D seismic reflection imaging in crystalline terrains: Part 1, Data processing: Geophysics, 68, 274-285, doi: 10.1190/1.1543213.

Nelson, R. G., 1980, Seismic investigations of the Mt. Isa ore deposit: Confidential report, South Australia Department of Mines \& Energy.

Nelson, R. G., 1984, Seismic reflection and mineral prospecting: Exploration Geophysics, 15, 229-250, doi: 10.1071/EG984229.

Noponen, I. T., P. J. Hirkkinen, and S. Mehrotra, 1979, Applicability of seismic reflection sounding in regions of Precambrian geology: Geoexploration, 17, 1-9, doi: 10.1016/0016-7142(79)90002-4.

Oblogina, T. I., V. B. Bilp, and S. Kochiai, 1962, The use of seismic methods to study intrusives, IZV: Geophysics Services, 1191-1205.

Odgers, A. T. R., R. C. Hinds, and G. von Gruenewaldt, 1993, Interpretation of a seismic reflection survey across the southern Bushveld Complex: South African Journal of Geology, 96, 205-212.

Perozzi, L., E. Gloaguen, S. Rondenay, and G. McDowell, 2012, Using stochastic crosshole seismic velocity tomography and Bayesian simulation to estimate Ni grades: Case study from Voisey's Bay, Canada: Journal of Applied Geophysics, 78, 85-93, doi: 10.1016/j.jappgeo.2011 06.036.

Perron, G., and A. J. Calvert, 1998, Shallow, high-resolution seismic imaging at the Ansil mining camp in the Abitibi greenstone belt: Geophysics, 63, 379-391, doi: 10.1190/1.1444337.

Perron, G., D. W. Eaton, B. Elliot, and D. Schmitt, 2003, Application of downhole seismic imaging to map near-vertical structures: Normétal (Abitibi Greenstone Belt), Québec, in D. W. Eaton, B. Milkereit, and M. H. Salisbury, eds., Hard rock seismic exploration: SEG, 194-206.

Perron, G., B. Milkereit, L. E. Reed, M. Salisbury, E. Adam, and J. Wu, 1997, Integrated seismic reflection and borehole geophysical studies at Les Mines Selbaie, Quebec: CIM Bulletin, 90, 75-82.

Peterson, J. E., B. N. P. Paullson, and T. V. McEvilly, 1985, Applications of algebraic reconstruction techniques to crosshole seismic data: Geophysics, 50, 1556-1580, doi: 10.1190/1.1441847.

Pretorius, C. C., M. Gibson, and Q. Snyman, 2011, Development of high resolution 3D vertical seismic profiles: Journal of the South African Institute of Mining and Metallurgy, 111, 117-125.

Pretorius, C. C., A. A. Jamison, and C. Irons, 1989, Seismic exploration in the Witwatersrand Basin, Republic of South Africa: Proceedings Exploration 87, Third Decennial International Conference on Geophysics and Geochemoical Exploration for Minerals and Groundwater: Special Publication, Ontario Geologic Survey, 3, 241-253

Pretorius, C. C., M. R. Muller, M. Larroque, and C. Wilkins, 2003, A review of 16 years of hard rock seismics on the Kaapvaal Craton, in Eaton, D. W., B. Milkereit, and M. H. Salisbury, eds., Hard rock seismic exploration: SEG, 247-268.

Pretorius, C. C., W. H. Steenkamp, and R. G. Smith, 1994, Developments in data acquisition, processing, and interpretation over ten years of deep vibroseismic surveying in South Africa: Proceedings XV CMMI Congress: SAIMM Symposium Series SI4, 3, 249-258.

Pretorius, C. C., and W. F. Trewick, 1997, Application of 3D seismics to mine planning at Vaal Reefs Gold Mine, number 10 shaft, Republic of South Africa: Proceedings of Exploration 97: Fourth Decennial International Conference on Mineral Exploration, Prospecting and Development Associates of Canada, 399-408.

Pretorius, C. C., W. F. Trewick, A. Fourie, and C. Irons, 2000, Application of 3D seismics to mine planning at Vaal Reefs Gold Mine, number 10 shaft, Republic of South Africa: Geophysics, 65, 1862-1870, doi: 10.1190/1 .1444870 .

Pretorious, C. C., W. F. Trewick, and C. Irons, 1997, Application of 3D-seismics to mine planning at the Vaal Reefs Gold Mine, number 10 shaft, Republic of South Africa: Proceedings of Exploration97, 399-408.
Price, T. O., 1974, Acoustical holography as a tool for geologic prediction: Subsurface exploration for underground excavation and heavy construction: ASCE.

Read, J. J., 1989, Seismic reflection investigations of the Hellyer orebody and Que-Hellyer volcanics, north west Tasmania: Exploration Geophysics, 20, 159-162.

Reed, K., 1993, Seismic reflection surveying for mining exploration applications, A review of practice past and current with an outlook for the future: Mineral Industry Technology Council of Canada, (unpublished report), 219.

Reid, A. B., L. G. Polome, and B. W. Greene, 1979, Ultra-high resolution reflection seismics in chromite detection: Presented at the 49th Annual International Meeting, SEG.

Roberts, B., E. Zaleski, G. Perron, E. Adam, L. Petrie, and M. Salisbury, 2003, Seismic exploration of Manitouwadge greenstones belt, Ontario: A case history, in D. W. Eaton, B. Milkereit, and M. H. Salisbury, eds. Hard rock seismic exploration: SEG, 110-126.

Roy, B., and R. Clowes, 2000, Seismic and potential-field imaging of the Guichon Creek batholith, British Columbia, Canada, to delineate structures hosting porphyry copper deposits: Geophysics, 65, 1418-1434, doi: $10.1190 / 1.1444831$.

Ruskey, F., 1981, High resolution seismic methods for hard rock mining: In premining investigations for hardrock mines: Proceedings U. S. Bureau of Mines Technology Transfer Seminar, 4-28.

Salisbury, M. H., C. W. Harvey, and L. Matthews, 2003, The acoustic properties of ores and host rocks in hardrock terranes, in D. W. Eaton, B. Milkereit, and M. H. Salisbury, eds., Hard rock seismic exploration: SEG, 9-19.

Salisbury, M. H., B. Milkereit, G. Ascough, R. Adair, L. Matthews, D. R. Schmitt, J. Mwenifumbo, D. W. Eaton, and J. Wu, 2000, Physical properties and seismic imaging of massive sulfides: Geophysics, 65, 1882-1889, doi: $10.1190 / 1.1444872$

Salisbury, M. H., B. Milkereit, G. L. Ascough, R. Adair, D. Schmitt, and L. Matthews, 1997, Physical properties and seismic imaging of massive sulphides: Proceedings of Exploration 97, Fourth Decennial International Conference on Mineral Exploration, 383-390.

Salisbury, M. H., B. Milkereit, and W. Bleeker, 1996, Seismic imaging of sulfide deposits: Part I. Rock properties: Economic Geology, 91, 821828, doi: 10.2113 /gsecongeo.91.5.821.

Salisbury, M. H., and D. Snyder, 2007, Application of seismic methods to mineral exploration, in W. D. Goodfellow, ed., Mineral deposits of canada: A synthesis of major deposit types, district metallogeny, the evolution of geological provinces, and exploration methods: Geological Association of Canada, Mineral Deposits Division, Special Publication 5 , 971-982.

Schmelzbach, C., H. Horstmeyer, and C. Juhlin, 2007, Shallow 3D seismic reflection imaging of fracture zones in crystalline rock: Geophysics, $\mathbf{7 2}$ no. 6, B149-B160, doi: 10.1190/1.2787336.

Schmidt, G., 1959, Results of underground seismic reflection investigations in siderite district of the Siegerland: Geophysical Prospecting, 7, 287290, doi: 10.1111/gpr.1959.7.issue-3.

Schodde, R. C., 2011, Recent trends in Australian exploration: presentation to the AMEC 2011 National Mining Congress, http://www.minexconsulting .com/publications/jun2011.html, accessed November 2011.

Sharov, N. V., 1997, Seismogeological model of North Europe lithosphere: Laplandsko-Pechengskii region, Apatity, Kola Science Centre Russian Academy of Science (in Russian).

Shopin, Y. G., 1981, Method of seismic mapping of nickel massives in Pechenga region: Leningrad mining Institute (in Russian).

Sinadinovski, C., S. A. Greenhalgh, and I. M. Mason, 1995, Three-dimensional reflector imaging of in-mine high frequency seismic data: Exploration Geophysics, 26, 325-330, doi: 10.1071/EG995325.

Skyttä, P., T. Hermansson, S.-Å. Elming, and T. Bauer, 2010, Magnetic fabrics as constraints on the kinematic history of a pre-tectonic granitoid intrusion, Kristineberg, northern Sweden: Journal of Structural Geology, 32, 1125-1136, doi: 10.1016/j.jsg.2010.06.020.

Snyder, D. B., P. Cary, and M. Salisbury, 2009, 2D-3C high-resolution seismic data from the Abitibi Greenstone Belt, Canada: Tectonophysics, 472, 226-237, doi: 10.1016/j.tecto.2008.05.038.

Spathis, A. T., D. Blair, and J. R. Grant, 1985, Seismic pulse assessment of the changing rock mass conditions induced by mining processes: International Journal of Rock Mechanics and Mining Sciences and Geomechanics Abstracts, 22, 303-312, doi: 10.1016/0148-9062(85) 92062-5.

Spencer, C. P., J. G. Thurlow, J. A. Wright, D. White, P. Carroll, B. Milkereit, and L. Reed, 1993, A vibroseis reflection seismic survey at the Buchans Mine in central Newfoundland: Geophysics, 58, 154-166, doi: $10.1190 / 1.1443345$.

Stevenson, F., R. M. A. Higgs, and R. J. Durrheim, 2003, Seismic imaging of precious and base-metal deposits in Southern Africa, in D. W. Eaton, B. Milkereit, and M. H. Salisbury, eds., Hard rock seismic exploration: SEG, 141-156. 
Stolz, E., M. Urosevic, and K. Connors, 2004, Reflection seismic surveys at St. Ives gold mine, WA: Preview, 111, 79.

Stuart, G. W., S. J. Jolley, L. G. B. T. Palome, and R. F. Tucker, 2000, Application of 3-D seismic attributes analysis to mine planning: Target gold deposit, South Africa: The Leading Edge, 19, 736-742.

Trickett, J., W. Duweke, and S. Kock, 2005, Three dimensional reflection seismic: Worth its weight in platinum!: Journal of the South African Institute of Mining and Metallurgy, 105, no. 5, 252-263.

Trickett, J., W. Düweke, and S. Kock, 2007, Three-dimensional reflection seismics surfs the crest of the platinum wave. Proceedings of the 10th Biennial Technical Meeting and Exhibition of the South African Geophysical Association.

Trickett, J., W. Düweke, L. Linzer, S. Kock, and K. Tootal, 2009, From aspirin to "the bin" in a mere 85 years: Proceedings of the 11th Biennial Technical Meeting and Exhibition of the South African Geophysical Association.

Tryggvason, A., A. Malehmir, J. Rodriguez-Tablante, C. Juhlin, and P. Weihed, 2006, Seismic reflection investigations in the western part of the Palaeoproterozoic Skellefte Ore District, northern Sweden: Economic Geology, 101, 1039-1054, doi: 10.2113/gsecongeo.101.5.1039.

Tucker, R. E., G. C.-J. Schlegel, J. H. E. Wagener, and N. K. Gray, 1994, The sun project-II. Scientific and technological innovations in a Witwatersrand exploration venture, in C. R. Anhaeusser, ed., Proceedings XV CMMI Congress: SAIMM Symposium Series S14, 3, 103-116.

Urosevic, M., and B. Evans, 1998, Seismic methods for the detection of kimberlite pipes: Exploration Geophysics, 29, 632-635.

Urosevic, M., and B. Evans, 2000, Surface and borehole methods to delineate kimberlite pipes in Australia: The Leading Edge, 19, 756-758, doi: 10 $.1190 / 1.1438712$

Urocevic, M., B. Ganesh, and G. Marcos, 2012, Targeting nickel sulphide deposits from 3D seismic reflection data at Kambalda, Australia: Geophysics, 77, this issue.

Urosevic, M., A. Kepic, C. Juhlin, and E. Stolz, 2008, Hard rock seismic exploration of ore deposits in Australia: Post-convention workshop on high-resolution seismic methods: 77th Annual International Meeting, SEG, Expanded Abstracts, 3613-3614.

Urosevic, M., A. Kepic, E. Stolz, and C. Juhlin, 2007, Seismic exploration of ore deposits in Western Australia: Proceedings of Exploration 07: Fifth Decennial International Conference on Mineral Exploration, 525-534.

Urosevic, M., E. Stoltz, and S. Massey, 2005, Seismic exploration for gold in a hard rock environment - Yilgarn Craton, Western Australia: 67th Annual International Conference and Exhibition, EAGE, Extended Abstracts, G009.

Verpaelst, P., A. S. Peloquin, E. Adam, A. E. Barnes, J. N. Ludden, D. J. Dion, C. Hubert, B. Milkereit, and M. Labrie, 1995, Seismic reflection profiles across the "Mine Series" in the Noranda camp of the Abitibi Belt, eastern Canada: Canadian Journal of Earth Sciences, 32, 167-176, doi: 10 $.1139 / \mathrm{e} 95-014$

Vestrum, R., and J. Gittins, 2009, Technologies from foothills seismic imaging: Replacement or complements?: First Break, 27, 61-66.

Weder, E. E. W., 1994, Structure of the area south of the Central Rand Gold Mines as derived from gravity and vibroseis surveys, in C. R. Anhaeusser, ed., Proceedings XV CMMI Congress: SAIMM Symposium Series S14, 3, 271-281.

White, D. J., D. E. Boerner, J. Wu, S. B. Lucas, E. Berrer, J. Hannila, and R. Somerville, 1997, High-resolution seismic and controlled-source EM studies near Thompson, Manitoba: Proceedings of Exploration 97, Fourth Decennial International Conference on Mineral Exploration, 685-694.

White, D., D. Boerner, J. Wu, S. Lucas, E. Berrer, J. Hannila, and R. Somerville, 2000, Mineral exploration in the Thompson nickel belt, Manitoba, Canada, using seismic and controlled-source EM methods: Geophysics, 65, 1871-1881, doi: 10.1190/1.1444871.

White, D. J., Z Hajnal, B Roberts, I Gyorfi, B Reilkoff, G. Bellefleur, C Mueller, S. Woelz, C. J. Mwenifumbo, E. Takacs, D. R. Schmitt, D. Brisbin, C. W. Jefferson, R. Koch, B. Powell, and I. R. Annesley, 2007, Seismic methods for uranium exploration: An overview of EXTECH IV seismic studies at the McArthur River mining camp, Athabasca Basin, Saskatchewan, in C. W. Jefferson, and G. Delaney, eds., EXTECH IV: Geology and uranium exploration technology of the Proterozoic Athabas- ca Basin, Saskatchewan and Alberta, Geological Survey of Canada, Bulletin 588 (also Saskatchewan Geological Society, Special Publication 17; Geological Association of Canada, Mineral Deposits Division, Special Publication 4, 363-388.

White, D., and B. Kjarsgaard, 2012, Seismic delineation of the Orion South kimberlite, Fort à la Corne, Canada: Geophysics, 77, this issue.

White, D. J., B. A. Kjarsgaard, C. J. Mwenifumbo, and G. Buffett, 2007 , Seismic delineation of the Orion South (140/141) kimberlite Fort a la Corne Field, Saskatchewan: Proceedings of Exploration 07: Fifth Decennial International Conference on Mineral Exploration, 1159-1163.

White, D. J., and M. Malinowski, 2012, Interpretation of 2D seismic profiles in complex geological terrains: Examples from the Flin Flon Mining Camp, Canada: Geophysics, 77, this issue.

White, D. J., B. Milkereit, J. Wu, M. H. Salisbury, J. Mwenifumbo, E. K. Berrer, W. Moon, and G. Lodha, 1994, Seismic reflectivity of the Sudbury Structure North Range from borehole logs: Geophysical Research Letters, 21, 935-938, doi: 10.1029/93GL02609.

White, D. J., D. Secord, and M. Malinowski, 2012, 3D seismic imaging in the Flin Flon VMS mining camp: Part I - Seismic results: Geophysics, 77, this issue.

Williams, N. C., R. Lane, and P. Lyons, 2004, Regional constrained 3D inversion of potential field data from the Olympic $\mathrm{Cu}-\mathrm{Au}$ province, south Australia: Preview, 109, 30-33.

Willman, C. E., R. J. Korsch, D. H. Moore, R. A. Cayley, V. A. Lisitsin, T. J. Rawling, V. J. Morand, and P. J. O'Shea, 2010, Crustal-scale fluid pathways and source rocks in the Victorian Gold Province, Australia: Insight from deep seismic reflection profiles: Economic Geology, 105, 895-915, doi: 10.2113 /gsecongeo.105.5.895.

Wong, J., 2000, Crosshole seismic imaging of sulphide orebody delineation near Sudbury, Ontario, Canada: Geophysics, 65, 1900-1907, doi: 10 $.1190 / 1.1444874$.

Wong, J., P. Hurly, and G. West, 1983, Crosshole seismology and seismic imaging in crystalline rocks: Geophysical Research Letters, 10, 491-496, doi: $10.1029 / \mathrm{GL} 010 \mathrm{i} 008 \mathrm{p} 00686$

Wong, J., P. Hurly, and G. West, 1984, Crosshole audio-frequency seismology in granitic rocks using piezoelectric transducers as sources and detectors: Geoexploration, 22, 261-279, doi: 10.1016/0016-7142(84) 90016-4.

Wood, G., C. O'Dowd, C. Cosma, and N. Enescu, 2012, An interpretation of surface and borehole seismic surveys for mine planning at the Millennium uranium deposit, northern Saskatchewan, Canada: Geophysics, 77, this issue.

Wright, C., J. A. Wright, and J. Hall, 1994, Seismic reflection techniques for base metal exploration in eastern Canada: Examples from Buchans, Newfoundland: Journal of Applied Geophysics, 32, 105-116, doi: 10.1016/ 0926-9851(94)90013-2.

Wright, P. M., 1981, Seismic methods in mineral exploration: Economic Geology, 863-870.

Wu, J., 1996, Potential pitfalls of crooked-line seismic reflection surveys Geophysics, 61, 277-281, doi: 10.1190/1.1443949.

Wu, J., B. Milkereit, and D. E. Boerner, 1995, Seismic imaging of the enigmatic Sudbury Structure: Journal of Geophysical Research, 100, 4117 4130, doi: $10.1029 / 94 J B 02647$.

Xu, K., and S. A. Greenhalgh, 2010, Ore body imaging by crosswell seismic waveform inversion: A case study from Kmabalda, Western Australia: Journal of Applied Geophysics, 70, 38-45, doi: 10.1016/j.jappgeo 2009.11.001.

Young, R. P., D. A. Hutchins, J. McGaughey, J. Towers, D. Jansen, and M. Bostock, 1989, Geotomographic imaging in the study of mine induced seismicity: Pure and Applied Geophysics, 129, 571-596, doi: 10.1007/ BF00874526.

Zaleski, E., W. D. Eaton, B. Milkereit, B. Roberts, M. Salisbury, and L. Petrie, 1997, Seismic reflections from subvertical diabase dikes in an $\mathrm{Ar}$ chean terrane: Geology, 25, 707-710, doi: 10.1130/0091-7613(1997) 025<0707:SRFSDD > 2.3.CO;2.

Zheng, Y., and R. R. Stewart, 1997, Side-scanning seismic imaging: A physical modeling study: Canadian Journal of Exploration Geophysics, 33, 21-28. 